J. Japan. Assoc. Min.

Petr. Econ. Geol.

$68,101-124,1973$

\title{
PETROLOGY AND LIQUIDUS TEMPERATURE OF THE MAGMA OF THE 1970 ERUPTION OF AKITA-KOMAGATAKE VOLCANO, NORTHEASTERN JAPAN
}

\author{
SHIgeo ARAMAKI \\ Earthquake Research Institute, University of Tokyo, \\ AND \\ TAKASHI Katsura \\ Department of Chemistry, Tokyo Institute of Technology
}

\begin{abstract}
The eruption of Akita-komagatake volcano in northern Honshu during the period September, 1970 - January, 1971, was characterized by the steady "Strombolian" type of eruption and the outlet of lava flows. The new magma was augite-hypersthene andesite $\left(\mathrm{SiO}_{2}=58 \%\right.$, mineralogy $\left.\mathrm{V}_{\mathrm{d} \rightarrow \mathrm{c}}\right)$ and definitely more acidic than basalts composing the Medake cone at the top of which the eruption occurred. Chemical compositions of the whole rock, groundmass, and glass are given together with microprobe analyses of augite, hypersthene, Ca-poor clinopyroxenes, plagioclase, titanomagnetite, etc. Ca-poor pyroxenes are the only pyroxene phases crystallizing in the stage immediately before and after the eruption. The wide scatter in composition of these Ca-poor pyroxenes probably reflects metastable condition of crystallization.

Controlled-atmosphere, high-temperature experiments on ejecta of 1970 eruption and artificial mixtures simulating groundmass glass composition indicate that the liquidus temperature of the magma at the time of eruption was close to $1100^{\circ} \mathrm{C}$, which is near the highest observed temperature $\left(1090^{\circ} \mathrm{C}\right)$ in the field. The plagioclase liquidus of the whole rock and groundmass composition is much higher than that of the pyroxenes while in the groundmass glass composition the difference is very small. The difference is attributed to the difference in water pressure of the magma in the reservoir and that at the time of eruption.
\end{abstract}

\section{INTRODUCTION AND ACKNOWL- EDGEMENTS}

The eruptive activity of Akita-komagatake volcano in 1970-1971 had been a rather monotonous, moderately explosive "Strombolian" eruption accompanied by the steady outlet of lava flows of pyroxene andesite. The activity may be considered to have been normal and simple for a Japanese volcano with andesitic magma. A set of detailed laboratory experiments on the ejecta were carried out in order to investigate the liquidus relations of the erupting magma with a hope that physical conditions of the volcanic eruptions may be clarified to any possible extent.

The present paper deals with the detailed mineralogy of the new ejecta (and the magma) and the results of high-temperature experiments at atmospheric pressure. The results strongly indicate that the magma before the eruption had been under low but appreciable water pressure as well as total pressure in the shallow reservoir or in the conduit. 
We thank Mr. Hiroshi Haramura, Geological Institute, University of Tokyo, for the chemical analyses by standard wet method. Our thanks are also due to $\mathrm{Mr}$. Osamu Ooshima and Dr. Takaaki Fukuoka who have provided us samples of the ejecta. Part of the expense was defrayed from the fund by the Ministry of Education. We are grateful to Dr. Ken-ichiro Aoki for critically reading the manuscript which greatly improved the content of this report.

\section{Geological Setting and the 1970-1971 ERUPTION}

Akita-komagatake volcano is located in the northern part of Honshu and is a part of a large Quaternary volcanic complex predominantly composed of pyroxene andesites ans some basalts (Kawano and Aoki, 1959, 1960; Yagi et al., 1972 a, b). The volcano is made up of several cones partly overlapping one upon another. The main cone, Odake (1,632 $\mathrm{m}$ above sea level) rests on the Tertiary sedimentary basement and is composed of an alternation of andesitic and basaltic lava flows and pyroclastic materials forming a strato-volcano more than $7 \mathrm{~km}$ in longer diameter.

A very large crater $(3 \times 1.5 \mathrm{~km})$, or possibly a caldera of unknown origin, occupies the southwestern part of the top of the stratovolcano. Inside the large crater, three central cones have grown during the latest stage of the development of Akita-komagatake volcano. Medake, the largest of the three central cones, occupies the northern part of the crater, rising more than $150 \mathrm{~m}$ from the floor of the crater (about $1,520 \mathrm{~m}$ above sea level). Medake is composed of an alternation of thin lava flows and pyroclastic materials forming a truncated coneshaped volcanic body. The lava is basaltic ( $\mathrm{SiO}_{2}=49.06-49.98 \%$, Kawano and Aoki,
1959; Кало, 1971) with a definite tholeitic affinity $\left(\mathrm{Na}_{2} \mathrm{O}=1.79-2.76 \%\right.$, and $\mathrm{K}_{2} \mathrm{O}=$ $0.21-0.35 \%$ ) carrying phenocrysts of olivine, augite and plagioclase. Detailed description of geology and petrology is given by Kawano and Aoki $(1959,1960)$ and Yagi et al. (1971, 1972).

The last activity took place at the top of Medake during the period from September 18, 1970, to January 26, 1971. Detailed chronology of the activity is given by Suwa et al. (1972), Kano (1971) and others (see special volume of Bulletin of Volcanological Society of Japan, 1972, vol. 16, pp. 63214).

Abnormal rise of surface temperature of the vent area was found about 3 weeks before the eruption started. The vent was located in one of the several depressions which occupy the hummocky top part of the Medake cone. Explosive activity was positively observed in the afternoon of September 18 but it possibly may have started a day before (Tanaka, 1972a). Throughout the whole period of activity which ended around January 26, 1971, the display of eruptive phenomena stayed rather monotonous: outburst of gas from the vent with detonation occurred in every several minutes, throwing essential fragments high up in the air and scattering them over the slope of Medake within a radius of $500 \mathrm{~m}$. Continuous outlet of lava flow accompanied the explosive activity. The main burst was usually followed by several successive smaller bursts which in turn followed by a period of quiet lasting 2 to 10 minuites in many cases. The phenomena may be described as "Strombolian" but the magma causing the eruption appeared to be more viscous than those producing the typical Strombolian eruptions. The essential fragments are 30 to more than $100 \mathrm{~cm}$ across, many of them 
are cow-dung shaped and others irregular, ribbon-shaped or of bread-crust type. No spindle-shaped bombs were produced and no red-hot surface of the head of the lava column was seen exposed inside the crater. Instead, the vent was covered with ejecta during the quiet period and a big outburst was usually heralded by rapid upswelling of the top part of the vent indicating that the vent stayed closed during the quiet period by viscous lava to allow gas pressure to build up and finally to lead to the next outburst. These features strongly indicated that the viscosity of the magma was higher than those responsible for a very typical Strombolian type of eruptions. An ordinary burst would propel semi-solid fragments to the height of 100 to $200 \mathrm{~m}$ with a maximum of $600 \mathrm{~m}$ above the vent. The maximum initial velocity and necessary gas pressure are about $90 \mathrm{~m} / \mathrm{sec}$ and 100 bars respectively (Suwa et al., 1972). By the end of activity a cinder cone about $60 \mathrm{~m}$ high with a crater about $60 \mathrm{~m}$ across was formed above the vent (Ossaka and Hirabayashi, 1972). The lava flow started flowing out of the vent

Table 1. Chemical composition of ejecta and lava flow of 1970 eruption of Akita-komagatake. Chemical analysis by $\mathrm{H}$. Haramura.

\begin{tabular}{|c|c|c|c|c|c|c|c|c|c|c|}
\hline $\begin{array}{c}\text { No. } \\
\text { Sample } \\
\text { Number }\end{array}$ & $\begin{array}{c}1 \\
\text { SA7009 } \\
2002 \mathrm{R}\end{array}$ & $\begin{array}{c}2 \\
\text { SA7010 } \\
1304 \mathrm{R}\end{array}$ & $\begin{array}{c}3 \\
007011 \\
04-2 A\end{array}$ & $\begin{array}{c}4 \\
007011- \\
04-1 \mathrm{~A}\end{array}$ & $\begin{array}{c}5 \\
\text { GRM-0 }\end{array}$ & $\begin{array}{c}6 \\
\text { GRM-1 }\end{array}$ & $\begin{array}{c}7 \\
G R M-2 \\
\end{array}$ & $\begin{array}{c}8 \\
G R M-3\end{array}$ & $\begin{array}{c}9 \\
\text { GRM-4 }\end{array}$ & $\begin{array}{c}10 \\
\text { GRM-5 }\end{array}$ \\
\hline $\mathrm{SiO}_{2}$ & 59.12 & 58.56 & 58.63 & 58.55 & 61.92 & 62.07 & 61.45 & 61.36 & 61.07 & 61.89 \\
\hline $\mathrm{TiO}_{2}$ & 0.96 & 0.99 & 1.02 & 0.94 & 0.90 & 1.03 & 0.92 & 0.93 & 0.94 & 1.07 \\
\hline $\mathrm{Al}_{2} \mathrm{O}_{3}$ & 16.46 & 16.66 & 16.30 & 16.43 & 14.23 & 14.24 & 14.19 & 14.41 & 14.38 & 15.23 \\
\hline $\mathrm{Fe}_{2} \mathrm{O}_{3}$ & 3.40 & 2.98 & 2.88 & 2.61 & 3.38 & 4.27 & 3.47 & 3.83 & 4.24 & 3.28 \\
\hline Feo & 5.78 & 6.19 & 6.44 & 6.68 & 5.60 & 4.90 & 5.84 & 5.56 & 5.25 & 5.68 \\
\hline $\mathrm{MnO}$ & 0.19 & 0.19 & 0.20 & 0.20 & 0.22 & 0.22 & 0.23 & 0.23 & 0.22 & 0.21 \\
\hline $\mathrm{MgO}$ & 2.84 & $2.86^{\circ}$ & 2.96 & 3.07 & 2.86 & 2.56 & 3.18 & 3.07 & 2.96 & 2.14 \\
\hline $\mathrm{CaO}$ & 7.30 & 7.34 & 7.37 & 7.44 & 6.16 & 5.91 & 6.25 & 5.98 & 5.87 & 6.07 \\
\hline $\mathrm{Na}_{2} \mathrm{O}$ & 3.50 & 3.55 & 3.39 & 3.51 & 3.83 & 3.96 & 3.76 & 3.68 & 3.66 & 3.88 \\
\hline $\mathrm{K}_{2} \mathrm{O}$ & 0.50 & 0.47 & 0.47 & 0.48 & 0.60 & 0.64 & 0.60 & 0.60 & 0.59 & 0.62 \\
\hline $\mathrm{H}_{2} \mathrm{O}(+)$ & 0.05 & 0.00 & 0.03 & 0.05 & 0.00 & 0.00 & 0.07 & 0.03 & 0.09 & 0.03 \\
\hline $\mathrm{H}_{2} \mathrm{O}(-)$ & 0.02 & 0.00 & 0.00 & 0,02 & 0.00 & 0.00 & 0.00 & 0.00 & 0.03 & 0.02 \\
\hline $\mathrm{P}_{2} \mathrm{O}_{5}$ & 0.11 & 0.12 & 0.12 & 0.11 & 0.10 & 0.09 & 0.13 & 0.14 & 0.17 & 0.11 \\
\hline Total & 100.23 & 99.91 & 99.81 & 100.09 & 99.80 & 99.89 & 100.09 & 99.82 & 99.74 & 100.23 \\
\hline $\mathrm{MgO}$ & 17.7 & 17.8 & 18.3 & 18.8 & 17.6 & 15.7 & 18.9 & 18.3 & 17.7 & 13.6 \\
\hline $\mathrm{Fe}_{2} \mathrm{O}_{3}+\mathrm{FeO}$ & 57.3 & 57.2 & 57.8 & 56.8 & 55.2 & 56.1 & 55.2 & 56.1 & 56.8 & 57.5 \\
\hline $\mathrm{Na}_{2} \mathrm{O}+\mathrm{K}_{2} \mathrm{O}$ & 25.0 & 25.0 & 23.9 & 24.4 & 27.1 & 28.2 & 25.9 & 25.6 & 25.5 & 28.9 \\
\hline$Q$ & 15.99 & 14.62 & 15.28 & 13.90 & 19.81 & 20.52 & 18.63 & 19.65 & 20.26 & 19.72 \\
\hline or & 2.95 & 2.62 & 2.78 & 2.84 & 3.56 & 3.78 & 3.54 & 3.54 & 3.49 & 3.66 \\
\hline$a b$ & 29.60 & 30.04 & 28.69 & 29.68 & 32.40 & 33.51 & 31.80 & 31.12 & 30.96 & 32.82 \\
\hline ал & 27.73 & 28.10 & 27.87 & 27.67 & 19.81 & 19.19 & 20.07 & 21.03 & 21.07 & 22.31 \\
\hline wo & 3.24 & 3.11 & 3.28 & 3.55 & 4.22 & 4.00 & 4.21 & 3.22 & 2.89 & 2.95 \\
\hline en & 7.07 & 7.12 & 7.37 & 7.64 & 7.12 & 6.37 & 7.92 & 7.64 & 7.37 & 5.33 \\
\hline fs & 6.57 & 7.62 & 8.12 & 8.92 & 5.53 & 4.18 & 6.77 & 5.94 & 4.99 & 6.34 \\
\hline $\mathrm{mt}$ & 4.93 & 4.33 & 4.17 & 3.80 & 4.86 & 6.18 & 5.03 & 5.55 & 6.15 & 4.76 \\
\hline il & 1.82 & 1.87 & 1.94 & 1.79 & 1.71 & 1.96 & 1.75 & 1.77 & 1.79 & 2.03 \\
\hline ap & 0.25 & 0.30 & 0.30 & 0.26 & 0.24 & 0.20 & 0.30 & 0.32 & 0.39 & 0.25 \\
\hline
\end{tabular}


immediately after the start of eruption and reached the base of the cone 10 days later. The lava flow was fed steadily by overflowing lava out of the vent throughout the active period and it showed typical aa surface (Macdonald, 1953; Wentworth and Macdonald, 1953). The natural levees were pronounced in the upper, steeper slope. The flow eventually formed a complicated multiflow compound lava field with many overlappings of the flow units. At the close of activity, the lava flow reached $1.2 \times 10^{\mathrm{A}} \mathrm{m}^{3}$ in volume occupying an area of $8 \times 10^{4} \mathrm{~m}^{2}$ (Ossaka and Hirabayashi, 1972). Total mass of ejected material and lava flow amounts to $3.6 \times 10^{13} \mathrm{~g}$ corresponding to the heat output of about $5 \times 10^{22} \mathrm{erg}$. The kinetic energy necessary to throuw up the projectiles is estimated as $1.6 \times 10^{20}$ erg (Suwa et al., 1972).

\section{Ghemistry and Mineralogy of THE NEW EJEGTA}

\section{Structure of the projectiles}

Two kinds of projectiles are distinguished although these two grade to each other: 1) bread-crust bombs and 2) irregularshaped volcanic blocks. Many of the breadcrust bombs have cores that are clearly distinguishable from the outer, freshly formed crust. It is probable that these cores were the fragmental ejectas once formed in the upper part of the vent but later were wrapped by the liquid magma to form the layered structure of the bombs.

The irregular-shaped blocks were apparently red-hot at the moment of ejection and upon their landing the grass and bush were set afire because of the heat. The blocks show black and very rugged spinose surface with plagioclase phenocrysts as white spots. The inner structure is regular with the following three zones: 1) outermost layer rich in glass, 2) oxidized zone with a reddish brown tinge, and 3 ) innermost zone more crystalline than zones 1) and 2). The cooling history of these spinose irregular

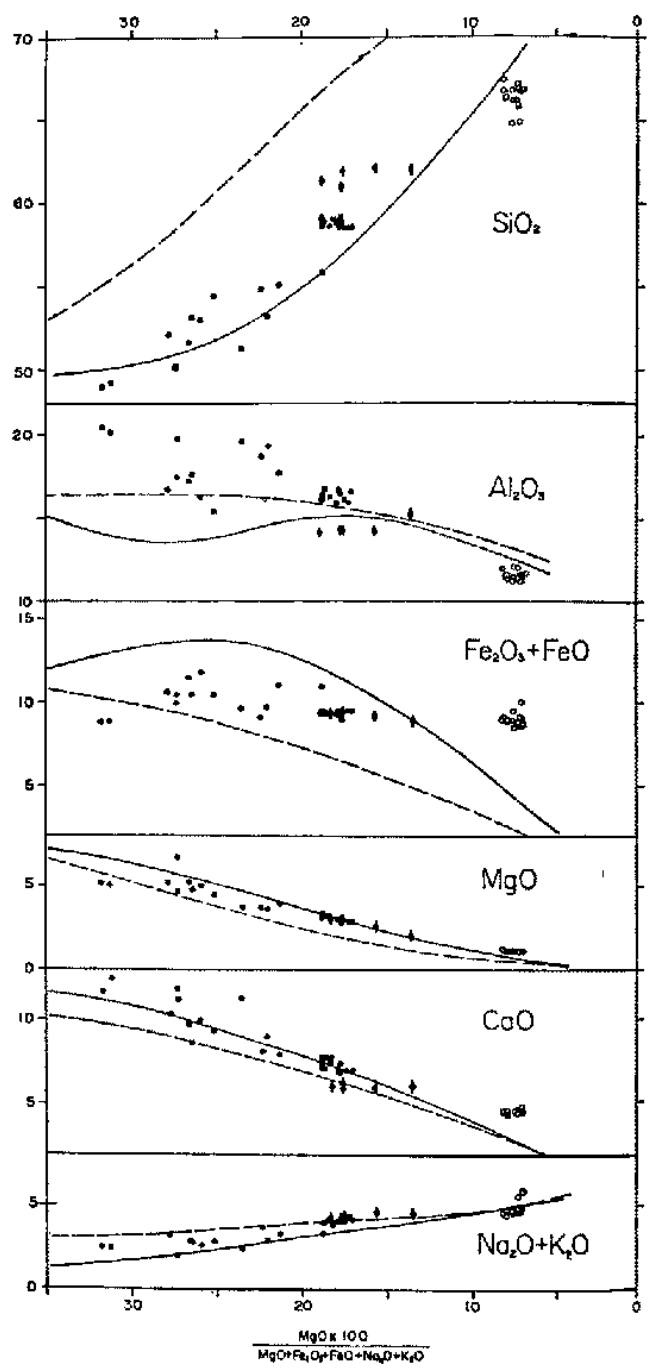

Fig. 1. Variation diagrams of the rocks of Akitakomagatake volcano including ejecta of 1970-1971 eruption. Vertical axis is the weight percent of oxides. Horizontal axis is the solidification index (SI) of Kuno (1954). Solid circles: lava, bombs, and blocks; solid circles with vertical bars: groundmass of 1970 ejecta; open circles: groundmass glass. Solid lines: trends of pigeonitic rock series; broken lines: trends of hypersthenic rock series of Izu-Hakone areas (Kuno, 1954). 
blocks may have been rather simple, and the samples used in the experiments were all taken from the outer zone 1) of this type of ejecta.

\section{Chemical composition}

Results of chemical analysis by standard wet method made by Mr. Hiroshi Haramura, Geological Institute, University of Tokyo, are given in Table 1. More than 20 whole rock analyses of the new ejecta and lava flows of the 1970-1971 eruption of Akita-komagatake are published (compiled by Aramaki, 1972, Tables 2 and 3). These analyses strongly indicate that the bulk composition did not change appareciably through the main part of the activity. It is also apparent that no difference exists between the compositions of projectiles and lava flows. Analyses in Table 1 are plotted in variation diagrams (Fig. 1) and A-M-F diagram (Fig. 2) together with selected analyses from other laboratories (see Aramaki, 1972).

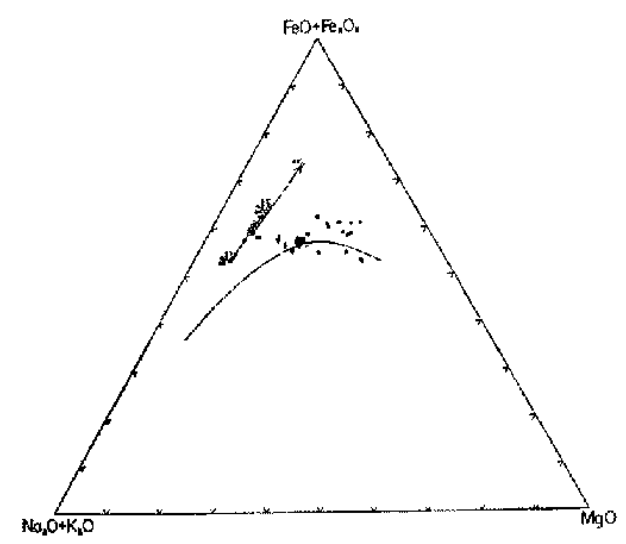

Fig. 2. A-M-F diagram of the rocks of Akitakomagatake volcano including ejecta of 1970-1971 eruption. Symbols are the same as Fig. 1. Open circles with dots $\langle\mathrm{G} 1, \mathrm{G} 2$, G3, and G4) represent compositions of groundmass glass corrected for the loss of Na during the measurement by electronprobe microanalyzer.
Compositions of the mechanically separated, fine-grained portion of the blocks are given in columns 5-10, Table 1 . The whole rock is crushed between 150 and 250 mesh and with the use of an isodynamic separator and Clerici's solution, phenocrysts are eliminated leaving the fractions corresponding to the groundmass made up of fine-grained crystals and glass. Variance in composition of the analyzed fractions (columns 5-10, Table 1) may be due to the fact that each fraction represents different concentrations of crystals and glass especially the different plagioclase-pyroxene ratios caused by different setting of the magnetic separator and density of the heavy liquid. This results from the difficulty in clearly distinguishing phenocrysts from groundmass microlites due to gradual changeover of their size.

In Table 2 and Figs. 1 and 2, are shown compositions of groundmass glass analyzed by electron probe microanalyzer (JOEL Model JXA-5; S.A. analyst). The same standards and method of measurement as those described by Nakamura and Kushiro (1970a) are used. The fact that the total of the analyses is less than $100 \%$ is mainly due to the loss of $\mathrm{Na}$ under the electron beam. It was necessary to use electron beams with diameter less than 20 microns in order to avoid microlites abundantly present in the groundmass. The analyses Gl- 1 through 4 are poorer due to smaller beams giving lower $\mathrm{Na}$ values. Analyses Gl-32 is especially corrected for the Na loss and is supposed to be closer to true values. The extent of $\mathrm{Na}$ loss is indicated in Fig. 2 for analyses Gl-1 through 4. Open circles indicated as Gl', G2', G3', and G4' are the plots of the original analyses and the G1, G2, G3, and G4 are those of recalculated values assuming that the deficiency in the total of analyses is all due to $\mathrm{Na}$ loss. Therefore, these re- 
Table 2. Chemical composition of groundmass glass of the ejecta of 1970 eruption of Akita-

\begin{tabular}{|c|c|c|c|c|c|c|c|}
\hline \multirow{2}{*}{$\begin{array}{l}\text { Sample } \\
\text { number }\end{array}$} & \multicolumn{4}{|c|}{ SA 70092002} & \multicolumn{3}{|c|}{ SA 70101304} \\
\hline & GL-1 & GL-2 & GL-3 & GL-4 & GL-22 & GL-23 & GL-24 \\
\hline $\mathrm{SiO}_{2}$ & 67.3 & 66.6 & 67.1 & 66.7 & 64.7 & 66.7 & 66,2 \\
\hline $\mathrm{TiO}_{2}$ & 1.35 & 1.36 & 1.37 & 1.34 & 1.29 & 1.22 & 1.40 \\
\hline $\mathrm{Al}_{2} \mathrm{O}_{3}$ & 12.00 & 11.63 & 11.45 & 11.44 & 11.24 & 12.08 & 11.59 \\
\hline $\mathrm{FeO}^{*}$ & 8.68 & 8.44 & 8.46 & 8.32 & 9.71 & 8.16 & 8.67 \\
\hline $\mathrm{MnO}$ & 0.21 & 0.20 & 0.22 & 0.22 & 0.21 & 0. 19 & 0.17 \\
\hline $\mathrm{MgO}$ & 1.22 & 1.12 & 1.13 & 1.10 & 1.13 & 1.04 & 1.14 \\
\hline $\mathrm{CaO}$ & 4.44 & 4.49 & 4.41 & 4.58 & 4.93 & 4.60 & 4.75 \\
\hline $\mathrm{Na}_{2} \mathrm{O}$ & 1.13 & 2.70 & 2.64 & 2.78 & 4.06 & 3.72 & 3.61 \\
\hline $\mathrm{K}_{2} \mathrm{O}$ & 0.79 & 0.87 & 0.83 & 0.89 & 0.90 & 0.83 & 0.81 \\
\hline Total & 97.1 & 97.4 & 97.6 & 97.4 & 98.2 & 98.5 & 98.3 \\
\hline $\mathrm{MgO}$ & 8.2 & 7.1 & 7.3 & 7.0 & 7.2 & 7.6 & 8.0 \\
\hline $\mathrm{FeO}^{*}$ & 58.9 & 53.8 & 54.6 & 53.1 & 61.4 & 59.4 & 60.9 \\
\hline $\mathrm{Na}_{2} \mathrm{O}+\mathrm{K}_{2} \mathrm{O}$ & 32.9 & 39.2 & 38.1 & 39.9 & 31.4 & 33.0 & 31.1 \\
\hline$Q$ & 43.8 & 35.3 & 36.8 & 35.1 & 25.2 & 30.1 & 29.1 \\
\hline or & 4.7 & 5.1 & 4.3 & 5.3 & 5.3 & 4.9 & 4.8 \\
\hline$a b$ & 9.6 & 22.8 & 22.3 & 23.6 & 34.3 & 31.5 & 30.5 \\
\hline an & 22.0 & 17.0 & 17.2 & 16.1 & 9.8 & 13.8 & 13.0 \\
\hline พо & $-1)$ & 2.2 & I. 9 & 2.8 & 6.1 & 3.8 & 4.4 \\
\hline en & 3.0 & 2.8 & 2.8 & 2.7 & 2.8 & 2.6 & 3.5 \\
\hline fs & 5.6 & 4.7 & 4.5 & 4.5 & 7,4 & 5.1 & 6.6 \\
\hline $\mathrm{mt}$ & 4.9 & 4.9 & 5.4 & 5.2 & 5.0 & 4.8 & 4.3 \\
\hline il & 2.6 & 2.6 & 2.6 & 2.5 & 2.5 & 2.3 & 2.7 \\
\hline
\end{tabular}

* Total Fe as FeO.

1) Including $\mathrm{C} 1.2$.

calculated values most probably represent overcorrection and the true values may fall somewhere in between.

In Fig. 1, analyses of older lavas composing the Akita-komagatake volcano are also plotted (solid circles with $\mathrm{SiO}_{2}$ less than $62 \%$ ). The new magma of 1970-1971 eruption appears to be the most siliceous among the lavas of Akita-komagatake volcano. Also interesting is the fact that lavas composing the cone of Medake, from the top of which the eruption of 1970-1971 took place, are the most mafic rocks of the whole volcano (olivine-augite basalt). Solid and broken lines are the variation trends of pigeonitic and hypersthenic rock series of the Izu-Hakone region (Kuno, 1954). Total iron, $\mathrm{MgO}$, and total alkalis of the rocks of Akita-komagatake volcano fall between the pigeonitic and hypersthenic rock series but $\mathrm{Al}_{2} \mathrm{O}_{3}$ and $\mathrm{CaO}$ are higher than the two rock series. This is probably due to the effect of abundant plagioclase phenocryst in Akita komagatake lavas while the variation trends of the Izu-Hakone rock series are for the non-porphyritic rocks. The composition of the groundmass glass is unusual in that it is higher in total iron and $\mathrm{CaO}$ (and to a less extent in $\mathrm{MgO}$ ) and lower in $\mathrm{SiO}_{2}$ and $\mathrm{Al}_{2} \mathrm{O}_{3}$.

Pronounced iron enrichment is also apparent in the A-M-F idagram (Fig. 2). 
komagatake. Analysis by electron-probe microanalyzer (analyst: S. Aramaki).

\begin{tabular}{|c|c|c|c|c|c|c|c|}
\hline \multicolumn{8}{|c|}{ SA 70101304} \\
\hline GL-25 & GL-26 & GL-27 & GL-28 & GL-29 & GL-30 & GL-31 & GL-32 \\
\hline 64.7 & 66.6 & 66.2 & 65.8 & 66.8 & 65.7 & 66.1 & 66.2 \\
\hline 1.28 & 1.49 & 1.31 & 1.38 & 1.29 & 1.24 & 1.30 & 1.30 \\
\hline 11.20 & 11.52 & 11.26 & 11.31 & 11.60 & 11.98 & 11.37 & 11.39 \\
\hline 9.18 & 8.85 & 8.61 & 8.68 & 8.80 & 8.46 & 8.69 & 8.69 \\
\hline 0.18 & 0.22 & 0.21 & 0.16 & 0.20 & 0.23 & 0.19 & 0.19 \\
\hline 1.17 & 1.18 & 1.16 & $1: 06$ & 1.07 & 1.03 & 1.12 & 1.12 \\
\hline 4.58 & 4.47 & 4.29 & 4.55 & 4.50 & 4.58 & 4.55 & 4.55 \\
\hline 4.02 & 3.71 & 3.95 & 3.94 & 3.83 & 3.76 & 3.97 & 4.46 \\
\hline 0.84 & 0.86 & 0.84 & 0.85 & 0.86 & 0.87 & 0.85 & 0.85 \\
\hline 97.2 & 98.9 & 97.8 & 97.7 & 99.0 & 97.9 & 98.1 & 98.8 \\
\hline 7.7 & 8.1 & 8.0 & 7.3 & 7.3 & 7.3 & 7.7 & 7.4 \\
\hline 60.3 & 60.6 & 59.1 & 59.7 & 60.5 & 59.9 & 59.3 & 57.5 \\
\hline 32.0 & 31.3 & 32.9 & 33.0 & 32.2 & 32.8 & 33.0 & 35.1 \\
\hline 26.0 & 29.5 & 28.4 & 27.9 & 29.1 & 28.1 & 27.8 & 25.5 \\
\hline 5.0 & 5.1 & 5.0 & 5.0 & 5.1 & 5.1 & 5.0 & 5.0 \\
\hline 34.0 & 31.4 & 33.4 & 33.3 & 32.4 & 31.8 & 33.6 & 37.7 \\
\hline 10.0 & 12.2 & 10.5 & 10.7 & 11.9 & 13.3 & 10.7 & 8.6 \\
\hline 5.3 & 4.1 & 4.5 & 5.0 & 4.3 & 3.9 & 5.0 & 5.9 \\
\hline 2.9 & 2.9 & 2.9 & 2.6 & 2.7 & 2.6 & 2.8 & 2.8 \\
\hline 7.3 & 6.8 & 6.8 & 6.6 & 6.9 & 6.8 & 6.8 & 6.8 \\
\hline 4.5 & 4.3 & 4.2 & 4.3 & 4.3 & 4.1 & 4.3 & 4.3 \\
\hline 2.4 & 2.8 & 2.5 & 2.6 & 2.5 & 2.3 & 2.5 & 2.5 \\
\hline
\end{tabular}

Dashed curve is the boundary between the thoeitic (pigeonitic) and calc-alkali (hypersthenic) rock series of the Tohoku region given by Kawano and Aoki (1959). The bulk and groundmass composition of the 1970 lavas fall close to this boundary curve. This is in accord with the kind of groundmass pyroxenes ( $V_{d \rightarrow c}$ according to Kuno's scheme) as recognized by many authors (Yagi et al., 1971; 1972; and others). In Fig. 3, relations between normative salic constituents are plotted. Solid circles with crosses represent bulk compositions of the rock, solid circles the compositions of separated groundmass and open circles those of glass. The right-hand side of Fig. 3 is a projection onto the Q-Or-Ab plane (petrogeny's residua system), and the left-hand side is the projection onto the $\mathrm{An}-\mathrm{Q}-(\mathrm{Ab}+$ Or) plane. Compositions of analyzed plagioclases (Table 4) are also plotted. When compared with the Japanese granitic rocks (Aramaki et al., 1970, 1972), the high $\mathrm{Na} / \mathrm{K}$ ratio of the Akita-komagatake specimens is the most conspicuous. Larger scatter in $\mathrm{Q} /$ $\mathrm{Ab}+$ Or ratio of the glasses is probably due to large errors in $\mathrm{Na}$-determination and may not be real.

\section{Composition of the magma and nature of eruption}

Typical andesitic volcanoes in Japan, 


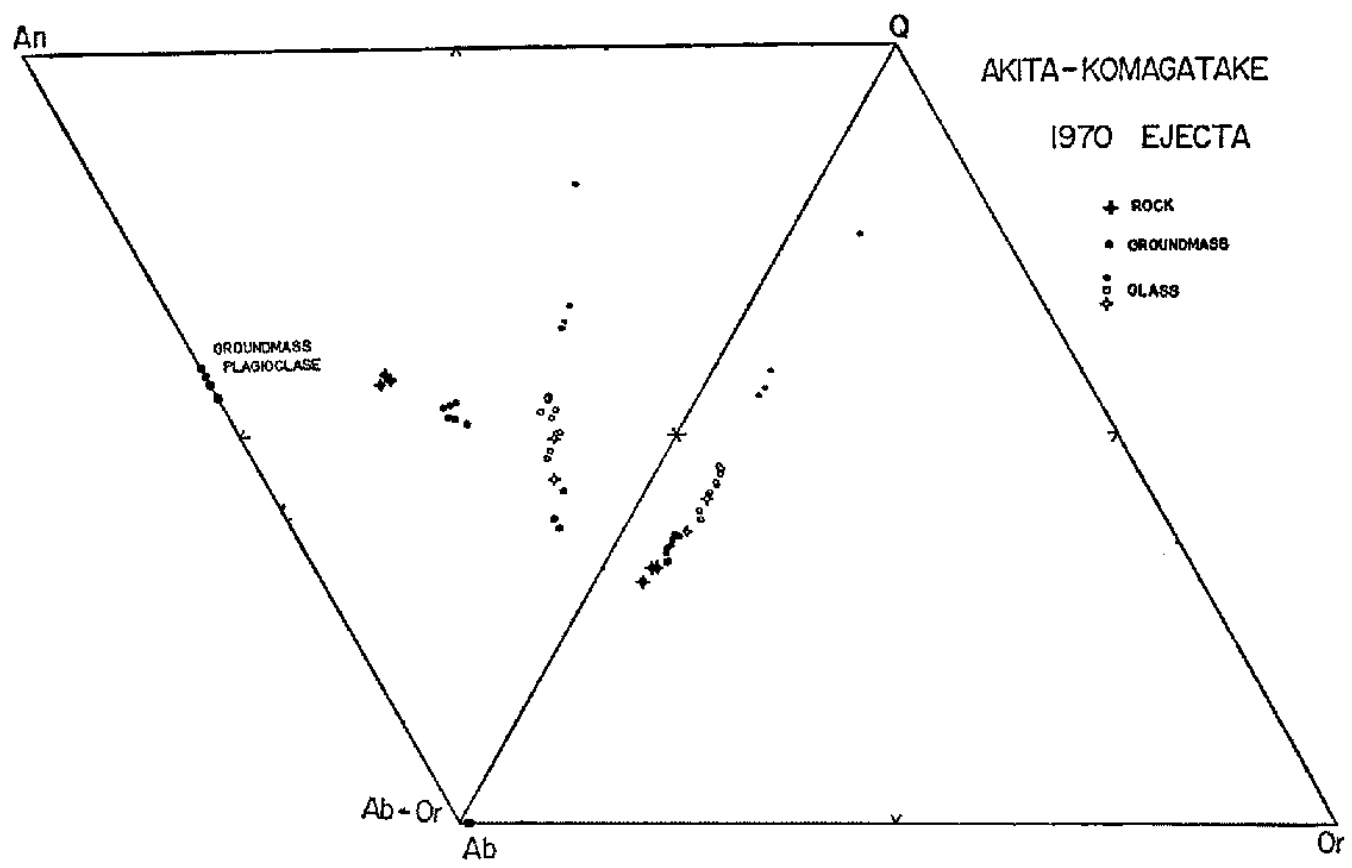

Fig. 3. Normative quartz and feldspars of the 1970 ejecta of Akita-komagatake volcano. Solid circles: groundmass; solid circles with crosses: whole rock; open circles: groundmass glass. For explanation see text.

such as Asama and Sakurajima display "Vulcanian" type of explosive activity. Although the column of liquid magma is considered to stand as high as the bottom of the open crater-pit and maintain hydrostatic equilibrium in these volcanoes, the explosion is much more violent and the intervening quiet period is much longer than the "Strombolian" activity displayed during the 1970-1971 eruption of Akita-komagatake. The projectiles are typical angular breadcrust bombs and dense blocks while cowdung driblets with spinose surface are generally absent. One is almost complelled to conclude that the magma of these Vulcanian explosions are more viscous than the magma of Akita-komagatake. However, the chemical composition of the projectiles are not much different from those of Akita-komagatake (both Sakurajima and Asama, $\mathrm{SiO}_{2}=$
$62 \%$ ). In reality, it was quite unexpected that the $\mathrm{SiO}_{2}$ content of 1970 ejecta of Akita-komagatake was as high as $58 \%$ after having observed such "Strombolian" eruptions. All the ejectas of the three volcanoes mentioned above carry about $30 \%$ of phenocrysts by volume. However, the effect of phenocrysts in raising the bulk viscosity should be rather insignificant even in the highly prophyrtic lavas as pointed out by Shaw (1963) but the viscosity as a controlling factor of the nature of the explosive eruption should be the viscosity of the truely liquid portion of the magma. If the composition of the analyzed glass of Akita-komagatake (Table 1) is compared with the groundmass composition of the $\mathbf{1 7 8 3}$ lava flow of Asama volcano (Aramaki, unpublished data; $\mathrm{SiO}_{2}=66.2 \%, \mathrm{Al}_{2} \mathrm{O}_{3}=15.3 \%, \mathrm{Fe}_{2} \mathrm{O}_{3}$ $=1.13 \%, \mathrm{FeO}=3.97 \%$ ), the Akita-koma- 
gatake glass (=liquid) is appreciably lower in $\mathrm{Al}_{2} \mathrm{O}_{3}$ and higher in iron than those of the Asama groundmass (=liquid). The $\mathrm{R}$ values defined by Shaw (1963), i.e., $R=$ $(\mathrm{Si}+\mathrm{Al} / \mathrm{O}$ is 0.456 for Akita-komagatake and 0.475 for Asama assuming the same degree of iron oxidation. From the Shaw's diagram (1963, Fig. 2), the discrepancy of 0.02 in $R$ at $1100-1200^{\circ} \mathrm{C}$ corresponds to the difference of one order of magnitude in $\eta$, which is comparable to that between basaltic and andesitic liquids. Therefore, it may be suggested that lower alumina coupled with high iron in the 1970 liquid of Akita-komagatake are responsible for the low viscosity and consequently Strombolian rather than Vulcanian type of activity.

\section{Modal composition}

The main constituents of the volcanic blocks and bombs and lava flows of the 1970 -1971 eruption are plagioclase, hypersthene, angite, titanomagnetite, pigeonite, subcalcic augite, and volcanic glass. Published modes of the new ejecta are summarized in Table 3. Large variance in phenocrystgroundmass ratios may be due to the diffculty of distinguishing between phenocrysts and groundmass minerals according to their sizes.

\section{Plagioclase}

Plagioclase ranges in size from more than $2 \mathrm{~mm}$ (phenocrysts) to less than several microns in the groundmass, and clear distinction between phenocrysts and groundmass is impossible. Larger crystals usually show marked oscillatory zoning, but grains with cores having distinctly different compositions are rare. Fig. 4 shows a microprobe traverse of such a case having calcic (about $\mathrm{An}_{\mathrm{g} 0}$ ) homogeneous core. The common oscillatory zoning, as shown in the outer margin of the plagioclase in Fig. 4 is rather random and does not display any recognizable regular pattern. Plagioclase crystals are relatively clear of inclusion with small amounts of magnetite and glass inclusions.

Table 3. Modal composition of ejecta and lava flow of Akita-komagatake, 1970-1971 eruption.

\begin{tabular}{|c|c|c|c|c|c|}
\hline & \multirow{2}{*}{ Source } & \multicolumn{2}{|c|}{ Soya (1971) } & \multirow{2}{*}{$\begin{array}{c}\text { Yagi et al. (1972) } \\
\text { new bomb } \\
\text { no. } 2306\end{array}$} & \multirow{2}{*}{$\begin{array}{c}\text { Aramaki-Haramura } \\
\text { (1971) } \\
\text { volcanie black } \\
\text { SA } 70092002\end{array}$} \\
\hline & & new lava & new bomb & & \\
\hline 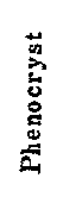 & $\begin{array}{l}\text { plagioclase } \\
\text { hypersthene } \\
\text { augite } \\
\text { magnetite } \\
\text { (subtotal) }\end{array}$ & $\begin{array}{r}14.5 \\
2.6 \\
2.5 \\
0.8 \\
(79.5)\end{array}$ & $\begin{array}{r}16.7 \\
2.2 \\
1.8 \\
0.7 \\
(21.4) \\
\end{array}$ & $\begin{array}{r}25.7^{1)} \\
3.0^{13} \\
2.5^{11} \\
2.15^{1)} \\
(33.4)^{2)} \\
\end{array}$ & $\begin{array}{r}20.1 \\
5.3 \\
4.9 \\
3.4 \\
(33.7) \\
\end{array}$ \\
\hline 苐品 & $\begin{array}{l}\text { glass } \\
\text { microlites } \\
\text { (subtotal) }\end{array}$ & $\begin{array}{c}39.3 \\
40.2 \\
(20.4)\end{array}$ & $\begin{array}{c}40.6 \\
38.0 \\
(78.6)\end{array}$ & $\begin{array}{c}53.2^{3)} \\
13.2 \\
(66.4)\end{array}$ & \}$_{(66.3)}^{66.3}$ \\
\hline \multicolumn{2}{|c|}{ Total } & 99.9 & 100.0 & 99.8 & $100.0^{41}$ \\
\hline \multicolumn{2}{|c|}{ Vesicles } & 19.3 & 37.3 & 32.0 & n.d. \\
\hline
\end{tabular}

1) Sum of phenocryst, microphenocryst and cognate inclusions.

2) Includes $0.04 \%$ of "deep brown glass".

3) Glass including microlites of pyroxene, feldspar, etc.

4) In weight $\%$. 
Smaller plagioclase crystals are euhedral showing well-defined rectangular sections. Some tiny prisms enclosed in glassy groundmass often have hollow ends and their cross section along the longer axis is forked at both ends. Chemical analyses of the plagioclase crystals are shown in Table 4. Phenocrysts are richer in $\mathrm{Ca}$ and poorer in $\mathrm{K}, \mathrm{Na}$, $\mathrm{Fe}, \mathrm{Ti}$, and $\mathrm{Mg}$ than goundmass crystals. Iron (total $\mathrm{Fe}$ as $\mathrm{FeO}$ ) in the groundmass plagioclase is around $1.0 \%$, a value much higher than those reported for igneous pla- gioclase (Deer et al., 1963, Table 16 etc.). Compared with plagioclases in the Columbia River basalts (Lindsley and Smith, 1971) and Deccan basalts (Aramaki and Shimizu, unpublished data), where iron enrichment has also proceeded in the groundmass stage, the Akita-komagatake plagioclase carry distinctly higher iron. The tendency that Al+ $\mathrm{Fe}$ is smaller than $\mathrm{Ca}+1.0$, which is reported by Lindsley and Smith (1971) for Columbia River basalts, is recognized also for the present case (Fig. 5) so that the possibility

Table 4. Chemical composition of plagioclase in the 1970 ejecta of Akita-komagatake volcano. Analysis by electron-probe microanalyzer.

\begin{tabular}{|c|c|c|c|c|c|c|c|c|}
\hline \multirow[t]{3}{*}{ Sample } & \multicolumn{5}{|c|}{ SA 70092002} & \multirow{2}{*}{\multicolumn{3}{|c|}{$\begin{array}{l}\text { SA 70101304 } \\
\text { groundmass }\end{array}$}} \\
\hline & \multicolumn{2}{|c|}{ phenocryst } & \multicolumn{3}{|c|}{ groundmass } & & & \\
\hline & 1 & 2 & 3 & 4 & 5 & 6 & 7 & 8 \\
\hline $\mathrm{SiO}_{2}$ & 51.5 & 49.1 & 54.9 & 53.7 & 53.2 & & & \\
\hline $\mathrm{TiO}_{2}$ & 0.04 & 0.04 & 0.07 & 0.08 & 0.06 & 0.06 & 0.06 & 0.05 \\
\hline $\mathrm{Al}_{2} \mathrm{O}_{3}$ & 30.6 & 30.4 & 26.8 & 26.7 & 27.0 & & & \\
\hline $\mathrm{FeO}^{*}$ & 0.73 & 0.70 & 1.02 & 1.02 & 0.89 & 0.93 & 1.02 & 1.01 \\
\hline $\mathrm{MnO}$ & n.d. & 0.01 & 0.00 & 0.00 & 0.00 & 0.03 & 0.04 & 0.02 \\
\hline $\mathrm{MgO}$ & 0.08 & 0.09 & 0.12 & 0.14 & 0.13 & 0.13 & 0.10 & 0.13 \\
\hline $\mathrm{CaO}$ & 14.6 & 14.1 & 11.0 & 11.7 & 12.1 & 11.22 & 12.00 & 11.52 \\
\hline $\mathrm{Na}_{2} \mathrm{O}$ & 3.33 & 3.82 & 4.93 & 4.88 & 4.82 & 5,02 & 4.58 & 4.78 \\
\hline $\mathrm{K}_{2} \mathrm{O}$ & 0.02 & 0.03 & 0.10 & 0.06 & 0.05 & 0.07 & 0.06 & 0.08 \\
\hline $\mathrm{Cr}_{2} \mathrm{O}_{3}$ & n.d. & n.d. & n.d. & n.d. & n.d. & 0.01 & 0.01 & 0.01 \\
\hline Total & 100.9 & 98.2 & 99.0 & 98.3 & 98.3 & & & \\
\hline \multicolumn{9}{|l|}{ 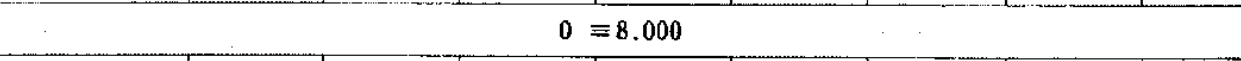 } \\
\hline $\mathrm{Si}$ & 2.33 & 2.29 & 2.51 & 2.48 & 2.46 & & & \\
\hline Al & 1.63 & 1.67 & $1.45^{-}$ & $1.45^{+}$ & 1.47 & & & \\
\hline $\mathrm{Fe}^{*}$ & 0.03 & 0.03 & 0.04 & 0.04 & 0.04 & & & \\
\hline $\mathrm{Si}+\mathrm{A} \mathrm{i}+\mathrm{Fe}^{*}$ & 3.99 & 3.99 & 3.99 & 3.98 & 3.97 & & & \\
\hline $\mathrm{Ti}$ & 0.001 & 0.002 & 0.002 & 0.003 & 0.002 & & & \\
\hline $\mathrm{Mn}_{\mathrm{n}}$ & $\cdots$ & 0.000 & 0.000 & 0.000 & 0.000 & & & \\
\hline $\mathrm{Mg}$ & 0.005 & 0.007 & 0.008 & 0.010 & 0.009 & & & \\
\hline $\mathrm{Ca}$ & 0.706 & 0.704 & 0.539 & 0.579 & 0.598 & & & \\
\hline $\mathrm{Na}$ & 0.292 & 0.345 & 0.437 & 0.437 & 0.433 & & & \\
\hline $\mathrm{K}$ & 0.001 & 0.002 & 0.006 & 0.004 & $0: 003$ & & & \\
\hline $\mathrm{Ca}+\mathrm{Na}+\mathrm{K}$ & 0.999 & 1.051 & 0.982 & 1.020 & 1.034 & & & \\
\hline \multirow{3}{*}{$\operatorname{mol}\left\{\begin{array}{l}A b \\
O r\end{array}\right.$} & 70.7 & 67.0 & 54.9 & 56.8 & 57.9 & 55.0 & 59.0 & 56.9 \\
\hline & 29.2 & 32.8 & 44.5 & 42.8 & 41.8 & 44.6 & 40.7 & 42.7 \\
\hline & 0.1 & 0.2 & 0.6 & 0.4 & 0.3 & 0.4 & 0.3 & 0.4 \\
\hline
\end{tabular}

* Total $\mathrm{Fe}$ as $\mathrm{FeO}$ or $\mathrm{Fe}^{2+}$. 


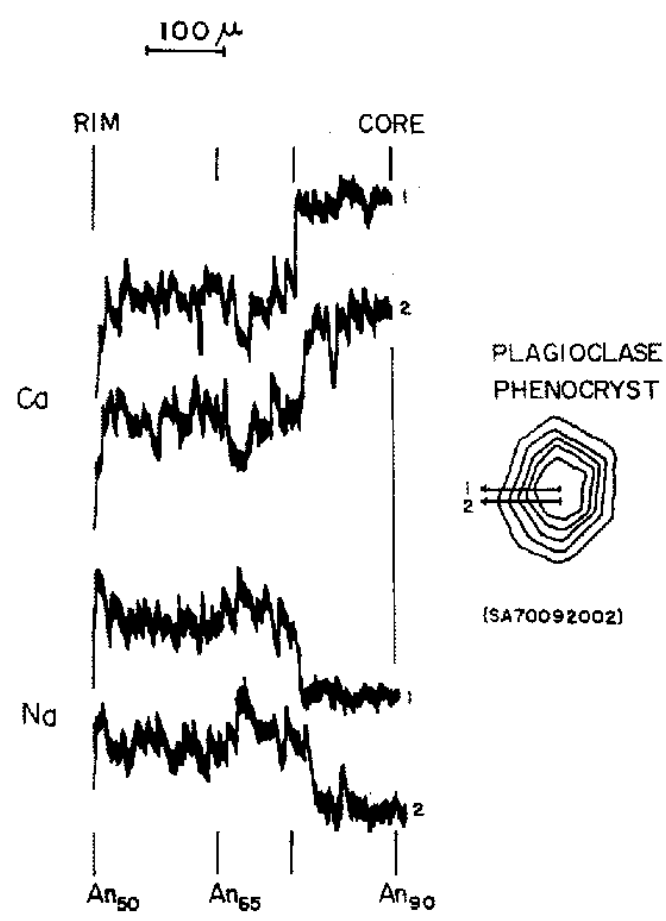

Fig. 4. Compositional prolfies ( $\mathrm{Na}$ and $\mathrm{Ca}$ ) across a plagioclase phenocryst from the 1970 ejecta. Scanning made by electron-probe microanalyzer.

of the substitution $\mathrm{Fe}^{2+}+\mathrm{Si}=2 \mathrm{Al}$ can not be denied.

\section{Pyroxenes}

Hypershene occurs in phenocrysts and groundmass microlites usually larger than 10 microns long. Grains smaller than several microns long appear to be all pigeonite and subcalcic augite as judged from microprobe and optical observations. Most of the hypersthene grains including larger ones are relatively homogeneous (Fig. 6) but some show a fine oscillatory zoning under the microscope. Composition of hypersthene phenocrysts and microphenocrysts (Figs. 7 and 8, Table 5) is normal for average Japanese andesites with a slight increase in $\mathrm{Ca}$ in microphenocrysts. $\mathrm{Mg}-\mathrm{Fe}$ partition coeffi-

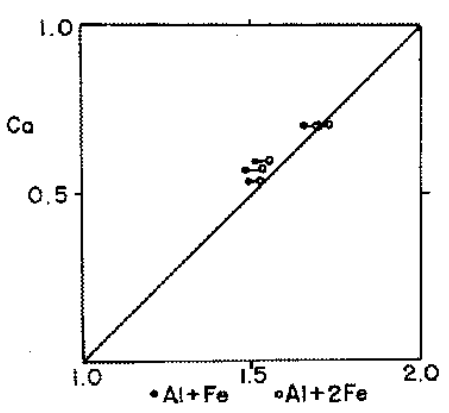

Fig. 5. Plot showing relation between $\mathrm{Ca}, \mathrm{Fe}$ and $\mathrm{AI}$ in plagioclase structural formula (Table 4). Solid circles: all $\mathrm{Fe}$ as $\mathrm{Fe}^{3+}$; open circles: all $\mathrm{Fe}$ as $\mathrm{Fe}^{2+}$ substituting as $\mathrm{CaFe}^{2+}+\mathrm{Si}_{3} \mathrm{O}_{8}$ molecule.

cients between augite and hypersthene (see tie-lines in Fig. 7) are $K_{d}=0.86$ for $a$ phenocryst pair and $K_{d}=0.93$ for a microphenocryst pair. In the groundmass of lava flows, where cooling was slower than in volcanic blocks and bombs, hypersthene crystals about several tens of microns long are surrounded by thin sleeves of Ca-poor clinopyroxene. In thin sections, overgrowth of clinopyroxene is most marked on faces parallel to $\mathrm{C}$-axis of hypersthene.

Occurrence of augite is the same as

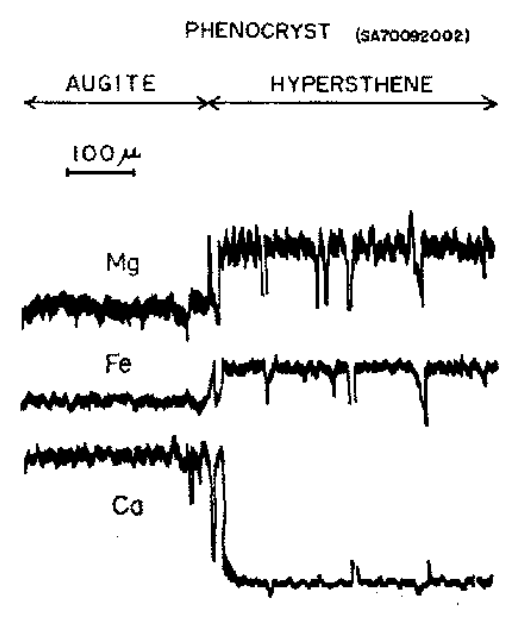

Fig. 6. Compositional profile of phenocrysts of augite and hypersthene in direct contact (a 1970 ejecta). Scanning made by electronprobe microanalyzer. 


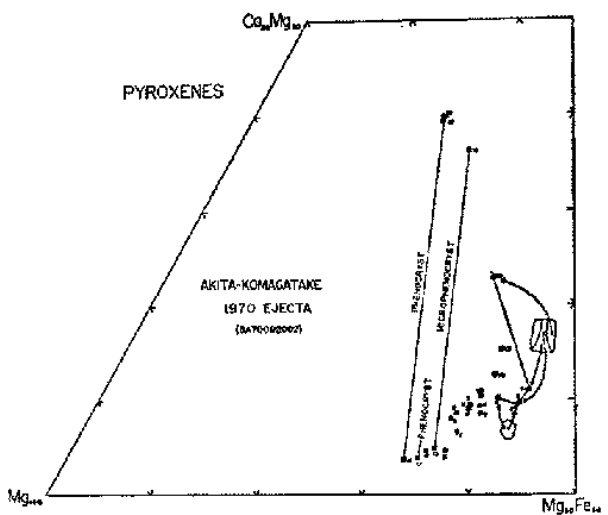

Fig. 7. Composition of pyroxenes from a volcanic block ejected on Sept. 20, 1970, Akitakomagatake volcano. All analyses by electron probe microanalyzer. Numbers indicate $\mathrm{Al}_{2} \mathrm{O}_{3}$ contents in weight percent multiplied by 10 .

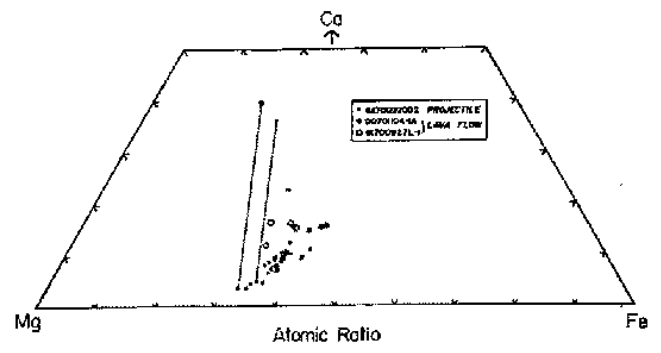

Fig. 8. Composition of pyroxenes from a block and two lava flow samples of the 19701971 eruption of Akita-komagatake. Small solid circles are the same as those in Fig. 7.

Table 5. Chemical composition of pyroxenes from an ejecta of Akita-komagatake (Sept. 20.

\begin{tabular}{|c|c|c|c|c|c|c|c|c|c|c|c|c|}
\hline & 1 & 2 & 3 & 4 & 5 & 6 & 7 & 8 & 9 & 10 & 11 & 12 \\
\hline & \multicolumn{9}{|c|}{$\begin{array}{l}\text { Augite micro- } \text { sucalcic augite hypersthene } \\
\text { phenocryst mi }\end{array}$} & \multicolumn{3}{|c|}{$\begin{array}{l}\text { pigeonite } \\
\text { microphenocryst }\end{array}$} \\
\hline $\mathrm{SiO}_{2}$ & 51.1 & 51.0 & 51.1 & 51.5 & 51.0 & 52.5 & 52.7 & 51.5 & 52.0 & 52.5 & 51.7 & 51.6 \\
\hline $\mathrm{TiO}_{2}$ & 0.54 & 0.58 & 0.54 & 0.49 & 0.51 & 0.32 & 0.32 & 0.40 & 0.27 & 0.40 & 0.32 & 0.53 \\
\hline $\mathrm{Al}_{2} \mathrm{O}_{3}$ & 2.23 & 2.13 & 1.76 & 1.41 & 1.26 & 1.10 & 1.04 & 1.22 & 0.82 & 1.48 & 0.86 & 1.63 \\
\hline $\mathrm{FeO}^{*}$ & 11.38 & 11.34 & 13.6 & 18.6 & 21.8 & 21.1 & 20.9 & 21,9 & 22.1 & 21.1 & 22.2 & 22.2 \\
\hline $\mathrm{MnO}$ & 0.39 & 0.46 & 0.47 & n.d. & 0.83 & 0.82 & 0.75 & 0.71 & n.d. & n.d. & $0.7 B$ & 0,69 \\
\hline $\mathrm{MgO}$ & 14.9 & 14.9 & 14.4 & 15.6 & 17.0 & 22.2 & 23.4 & 21.7 & 20.9 & 21.7 & 19.5 & 19.5 \\
\hline $\mathrm{CaO}$ & 19.3 & 19.6 & 17.4 & 10.69 & 7.48 & 1.84 & 1.92 & 2.41 & 2.16 & 2.27 & 4.48 & 4.48 \\
\hline $\mathrm{Na}_{2} \mathrm{O}$ & n.d. & n.d. & n.d. & n.d. & n.d. & n.d. & n.d. & n.d. & n.d. & n.d. & n.d. & n.d. \\
\hline $\mathrm{K}_{2} \mathrm{O}$ & n.d. & n.d. & n.d. & n.d. & n.d. & n.d. & n.d. & n.d. & n.d. & n.d. & n.d. & n.d. \\
\hline Total & 99.8 & 100.1 & 99.2 & 98.3 & 99.9 & 99.8 & 101.0 & 99.8 & 98.3 & 99.5 & 99.9 & 100.7 \\
\hline $\mathrm{Si}$ & 1.921 & 1.916 & 1.941 & 1.975 & 1.947 & 1.960 & 1.943 & 1.937 & 1.978 & 1.962 & 1.958 & 1.937 \\
\hline $\mathrm{Al}]^{\mathrm{IN}}$ & 0.079 & 0.084 & 0.059 & 0.025 & 0.053 & 0.040 & 0.045 & 0.054 & 0.022 & 0.038 & 0.038 & 0.063 \\
\hline $\mathrm{Al}^{\mathrm{VI}}$ & 0.020 & 0.010 & 0.020 & 0.038 & 0.004 & 0.008 & - & - & 0.015 & 0.027 & - & 0.009 \\
\hline $\mathrm{T}_{\mathrm{i}}$ & 0.015 & 0.016 & 0.015 & 0.014 & 0.015 & 0.009 & 0.009 & 0.011 & 0.008 & 0.011 & 0.009 & 0.015 \\
\hline $\mathrm{Fe}^{*}$ & 0.358 & 0.356 & 0.432 & 0.598 & 0.696 & 0.657 & 0.644 & 0.689 & 0.704 & 0.659 & 0.703 & 0.698 \\
\hline $\mathrm{Mn}$ & 0.013 & 0.015 & 0.015 & - & 0.027 & 0.026 & 0.024 & 0.023 & - & - & 0.025 & 0.022 \\
\hline $\mathrm{Mg}$ & 0.834 & 0.835 & 0.815 & 0.890 & 0.964 & 1.234 & 1.285 & 1.214 & 1.182 & 1.207 & 1.099 & 1.088 \\
\hline $\mathrm{Ca}$ & 0.775 & 0.790 & 0.707 & 0.439 & 0.306 & 0.073 & 0.076 & 0.097 & 0.088 & 0.091 & 0.182 & 0.180 \\
\hline $\mathrm{Na}$ & - & - & - & - & - & - & - & - & - & - & - & - \\
\hline $\mathrm{K}$ & - & - & - & - & - & - & - & - & - & - & - & - \\
\hline Z & 2.000 & 2.000 & 2.000 & 2.000 & 2.000 & 2.000 & 1.988 & 1.991 & 2.000 & 2.000 & 1.996 & 2.000 \\
\hline $\mathrm{W}+\mathrm{X}+\mathrm{Y}$ & 2.015 & 2.022 & 2.004 & 1.979 & 2.012 & 2.000 & 2.038 & 2.034 & 1.997 & 1.995 & 2.018 & 2.012 \\
\hline $\int \mathrm{Ca}$ & 39.4 & 39.9 & 36.2 & 22.8 & 15.6 & 3.7 & 3.8 & 4.9 & 4.5 & 4.6 & 9.2 & 9.2 \\
\hline $\mathrm{Mg}$ & 42.4 & 42.1 & 41.6 & 46.2 & 49.0 & 62.8 & 64.1 & 60.7 & 59.9 & 61.7 & 55.4 & 55.3 \\
\hline $\mathrm{Fe}$ & 18.2 & 18.0 & 22.2 & 31.0 & 35.4 & 33.5 & 32.1 & 34.9 & 35.6 & 33.7 & 35.4 & 35.5 \\
\hline
\end{tabular}


that of hypersthene and it is present only as phenocrysts and microphenocrysts (Table 5 and Fig. 7). The gap in $\mathrm{Ca}$ content between augite-hypersthene pairs is larger in phenocrysts than in microphenocrysts (see tie-lines in Fig. 7). Numbers in Fig. 7 indicate $\mathrm{Al}_{2} \mathrm{O}_{3}$ content in weight percent multiplied by 10 . Zoning is not pronounced in augites (Fig. 6).

Pigeonite and subcalcic augite are limited in microphenocrysts and groundmass microlites. As will be seen from Figs. 7 and 8 , the $\mathrm{Ca}$ content shows a wide fluctuation and the trend is not clearly defined like the groundmass pyroxenes studied by Naka- mura and Kushiro (1970a, b). They are euhedral with a tendency to elongate parallel with $c$-axis that is more pronounced in smaller grains than in larger ones. The Al content changes quite haphazardly with respect to $\mathrm{Ca}-\mathrm{Mg}-\mathrm{Fe}$ contents. In some grains like the ones shown in Fig. 7 (points connected by straight lines), the Ca-Mg-Fe composition as well as $\mathrm{Al}$ varies greatly from sector to sector within a single grain. These features all point to the fact that the Ca-poor pyroxenes crystallized out of the liquid rapidly and in pronouncedly metastable state. Two samples of the lava flow were measured for Ca-poor pyroxenes (Fig.

1970; SA 70092002). Analysis by electron-probe microanalyzer.

\begin{tabular}{|c|c|c|c|c|c|c|c|c|c|c|c|}
\hline 13 & 14 & 15 & 16 & 17 & 18 & 19 & 20 & 21 & 22 & 23 & 24 \\
\hline \multicolumn{12}{|c|}{$\begin{array}{l}\text { Pigeonite } \\
\text { groundmass }\end{array}$} \\
\hline 51.7 & 52.1 & 52.7 & 51.2 & 50.7 & 51.3 & 52.3 & 49.7 & 50.8 & 51.1 & 51.3 & 52.3 \\
\hline 0.35 & 0.25 & 0.24 & 0.33 & 0.29 & 0.32 & 0.53 & 0.37 & 0.36 & 0.28 & 0.35 & 0.34 \\
\hline 0.87 & 0.66 & 0.60 & 1.00 & 0.78 & 0.86 & 2.90 & 0.90 & 1.04 & 0.83 & 0.76 & 1.05 \\
\hline 22.8 & 22.5 & 21.8 & 21.9 & 21.6 & 21.8 & 21.5 & 22.9 & 21.9 & 21.6 & 23.9 & 24.0 \\
\hline 0.79 & 0.85 & 0.85 & 0.72 & 0.82 & 0.72 & 0.82 & 0.75 & n.d. & n.d. & n.d. & n.d. \\
\hline 19.1 & 20.4 & 20.5 & 18.2 & 19.8 & 18.1 & 15.4 & 17.7 & 17.3 & 18.9 & 17.0 & 16.2 \\
\hline 4.61 & 3.26 & 3.94 & 4.92 & 4.16 & 3.98 & 4.02 & 4.80 & 5.92 & 4.50 & 4.66 & 5.23 \\
\hline n.d. & n.d. & n.d. & 0.06 & 0.04 & 0.18 & 0.07 & 0.07 & nd. & n.d. & n.d. & n.d. \\
\hline n.d. & n.d. & n.d. & 0.02 & 0.01 & 0.11 & 0.06 & 0.00 & n.d. & nd. & n.d. & n.d. \\
\hline 100.2 & 100.0 & 100.6 & 98.3 & 98.1 & 97.4 & 97.6 & 97.2 & 97.3 & 97.1 & 98.0 & 99.2 \\
\hline 1.956 & 1.964 & 1.969 & 1.968 & 1.951 & 1.987 & 2.005 & 1.951 & 1.974 & 1.976 & 1.989 & 2.001 \\
\hline 0.039 & 0.029 & 0.027 & 0.032 & 0.035 & 0.013 & - & 0.042 & 0.026 & 0.024 & 0.011 & - \\
\hline- & - & - & 0.013 & - & 0.026 & 0.131 & - & 0.019 & 0.014 & 0.024 & 0.048 \\
\hline 0.010 & 0.007 & 0.007 & 0.009 & 0.008 & 0.009 & 0.015 & 0.011 & 0.010 & 0.008 & 0.010 & 0.010 \\
\hline 0.722 & 0.709 & 0.680 & 0.704 & 0.694 & 0.706 & 0.690 & 0.750 & 0.713 & 0.700 & 0.773 & 0.768 \\
\hline 0.025 & 0.027 & 0.027 & 0.023 & 0.027 & 0.024 & 0.027 & 0.025 & - & - & 一 & - \\
\hline 1.077 & 1.147 & 1.144 & 1.046 & 1.134 & 1.045 & 0.878 & 1.034 & 1.000 & 1.089 & 0.983 & 0.924 \\
\hline 0.187 & 0.132 & 0.158 & 0.203 & 0.172 & 0.165 & 0.165 & 0.202 & 0.246 & 0.187 & 0.193 & 0.214 \\
\hline- & - & - & 0.005 & 0.003 & 0.013 & 0.005 & 0.005 & - & 一 & - & - \\
\hline- & - & - & 0.001 & 0.001 & 0.005 & 0.003 & 0.000 & - & - & - & $\cdots$ \\
\hline 1.995 & 1.993 & 1.996 & 2.000 & 1.986 & 2.000 & 2.005 & 1.993 & 2.000 & 2.000 & 2.000 & 2.001 \\
\hline 2.020 & 2.022 & 2.016 & 2.004 & 2.038 & 1.993 & 1.914 & 2.027 & 1.969 & 1.998 & 1.983 & 1.964 \\
\hline 9.4 & 6.6 & 8.0 & 10.4 & 8.6 & 8.6 & 9.5 & 10.2 & 12.6 & 9.5 & 9.9 & 11.2 \\
\hline 54.2 & 57.8 & 57.6 & 53.6 & 56.7 & 54.5 & 50.7 & 52.0 & 51.1 & 55.1 & 50.4 & 48.5 \\
\hline 36.4 & 35.6 & 34.4 & 36.0 & 34.7 & 36.9 & .39 .8 & 37.8 & 36.3 & 35.4 & 39.7 & 40.3 \\
\hline
\end{tabular}




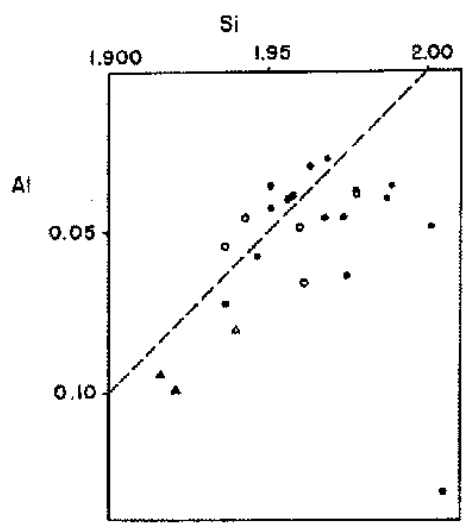

Fig. 9. Relation between $\mathrm{Al}$ and $\mathrm{Si}$ in structural formula of pyroxenes analyzed from the 1970 ejecta of Alkita-komagatake, Open triangles: augite phenocrysts; open circles: hypersthene phenocrysts and microphenocrysts; solid circles: Ca-poor groundmass pyroxenes.

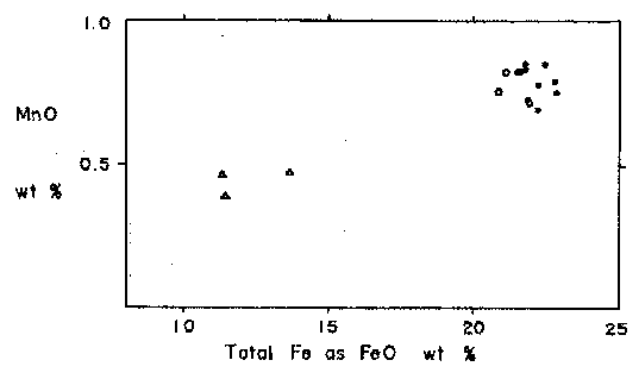

Fig. 10. $\mathrm{MnO}-\mathrm{FeO}$ (total $\mathrm{Fe}$ as $\mathrm{FeO}$ ) relations of analyzed pyroxenes. Symbols are the same as Fig. 9.

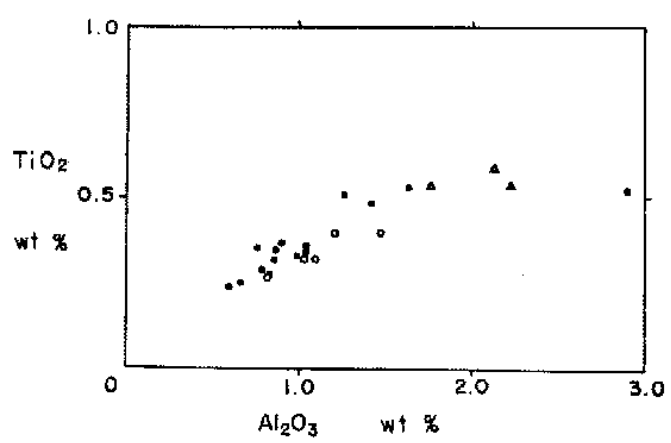

Fig. 11. $\mathrm{TiO}_{2} \cdot \mathrm{Al}_{2} \mathrm{O}_{3}$ relations of analyzed pyroxenes. Symbols are the same as those in Fig. 9.
8). One of the two (00701104-1A) show compositions falling in the same range as that of the ejected block (SA700920002) but the other (IL70092L-1) shows somewhat Ca-rich composition. No anomalous relations are observed between $\mathrm{Si}$ and $\mathrm{Al}$ (Fig. 9), $\mathrm{MnO}$ and total $\mathrm{Fe}$ (Fig. 10), and $\mathrm{TiO}_{2}$ and $\mathrm{Al}_{2} \mathrm{O}_{3}$ (Fig. 11).

\section{Titanomagnetite}

Magnetite occurs as phenocrysts up to $0.4 \mathrm{~mm}$ in diameter, as smaller euhedral grains down to a few microns and as dendritic crystals enclosed in glassy groundmass of lava flows. Smaller euhedral grains whose analyses are given in Table 6 as groundmass titanomagnetite appear to have crystallized in the same stage as the $\mathrm{Ca}$ poor clinopyroxenes discussed in the foregoing. They contain more than $40 \% \mathrm{~mol}$ ulvöspinel as recalculated according to Carmichael's method (1957), and the groundmass magnetites are richer in ulvöspinel molecule than phenocrysts. They are distinctly richer in $\mathrm{Al}_{2} \mathrm{O}_{3}$ and a little poorer in Mn than magnetite phenocrysts of felsic volcanic rocks given by Carmichael (1967), and very similar to magnetites of Futatsudake, Haruna volcano given by Ooshima (1971). Smaller grains contain more $\mathrm{Si}, \mathrm{Mn}$, and $\mathrm{Ca}$ and less $\mathrm{Ti}, \mathrm{Al}, \mathrm{Fe}$, and $\mathrm{Mg}$ than the larger (phenocrystic) grains.

\section{Tridymite and anhydrite in xenoliths}

The amount of accidental inclusions contained in the ejecta of 1970-1971 eruption is very small. Among these, white, often angular blocks of siliceous xenoliths are the most abundant. They consist of tridymite, anhydrite, augite, opaque $\mathrm{min}$ eral, and glass (Yagi et al., 1971, 1972). The xenoliths are considered to be pyrometamorphosed basement rocks of Neogene 
Table 6. Chemical composition of magnetite in the 1970 ejecta of Akita-komagatake volcano. Analysis by electron-probe microanalyzer.

\begin{tabular}{|c|c|c|c|}
\hline \multirow{3}{*}{$\begin{array}{l}\cdots \\
\ldots\end{array}$} & \multicolumn{3}{|c|}{ SA 70092002} \\
\hline & \multirow{2}{*}{$\frac{\text { phenocryst }}{1}$} & \multicolumn{2}{|c|}{ grou ndmass } \\
\hline & & 2 & 3 \\
\hline $\mathrm{SiO}_{2}$ & 0.12 & 0.17 & 0.22 \\
\hline $\mathrm{TiO}_{2}$ & 12.3 & 15.4 & 15.7 \\
\hline $\mathrm{Al}_{2} \mathrm{O}_{3}$ & 2.98 & 2.31 & 2.40 \\
\hline $\mathrm{FeO}^{*}$ & 76.6 & 72.6 & 74.2 \\
\hline $\mathrm{MnO}$ & 0.40 & 0.46 & 0.54 \\
\hline $\mathrm{MgO}$ & 2.03 & 1.80 & 1.71 \\
\hline $\mathrm{CaO}$ & 0.01 & 0.12 & 0.05 \\
\hline $\mathrm{Na}_{2} \mathrm{O}$ & n.d. & 0.00 & 0.04 \\
\hline $\mathrm{K}_{2} \mathrm{O}$ & n.d. & 0.01 & 0.00 \\
\hline Total & 94.5 & 92.8 & 94.8 \\
\hline \multicolumn{4}{|c|}{ recalculated on ulvöspinel basis } \\
\hline $\mathrm{FeO}$ & 41.6 & 41.6 & 42.5 \\
\hline $\mathrm{Fe}_{2} \mathrm{O}_{3}$ & 39.2 & 35.2 & 35.2 \\
\hline Total & 98.6 & 97.1 & 99.3 \\
\hline Ulvôspinel (mol \%) & 41.0 & 45.7 & 46.2 \\
\hline \multicolumn{4}{|c|}{$0=4.000$} \\
\hline $\mathrm{Ti}$ & 0.345 & 0.505 & 0.504 \\
\hline $\mathrm{Si}$ & 0.004 & 0.007 & 0.010 \\
\hline $\mathrm{Al}$ & 0.131 & 0.119 & 0.121 \\
\hline $\mathrm{Fe}^{3+}$ & 1.17 & 1.15 & 1.12 \\
\hline $\mathrm{Fe}^{2+}$ & 1.22 & 1.51 & 1.54 \\
\hline$M n$ & 0.013 & 0.017 & 0.020 \\
\hline $\mathrm{Mg}$ & 0.113 & 0.118 & 0.109 \\
\hline $\mathrm{Ca}$ & 0.001 & 0.005 & 0.002 \\
\hline
\end{tabular}

age. Microprobe analyses of the tridymites are given in Table 7.

\section{Controlled-Atmosphere High- TEMPERATURE EXPERIMENTS}

\section{Starting materials}

Starting materials used in high-temperature experiments are characterized in Tables 8 and 9. Two kinds of starting materials were prepared from the natural specimens: 1) finely-ground original samples and 2) completely remelted glass. The first was prepared by simply grinding the powder
Table 7. Chemical composition of tridymites in xenoliths. Analysis by $\mathrm{S}$. Aramaki with electron probe microanalyzer.

\begin{tabular}{l|c|c}
\hline & 1 & 2 \\
\hline Sample & $00701104-3$ & $\begin{array}{c}\text { Yagi et al. } \\
(1971,1972)\end{array}$ \\
\hline $\mathrm{SiO}_{2}$ & 99.1 & $97.8_{5}$ \\
$\mathrm{Al}_{2} \mathrm{O}_{3}$ & 0.35 & 0.47 \\
$\mathrm{FeO}^{*}$ & 0.02 & 0.00 \\
$\mathrm{CaO}$ & 0.00 & 0.01 \\
\hline Total & $99.5^{-}$ & 98.3 \\
\hline
\end{tabular}

$\mathrm{FeO}^{*}=$ total $\mathrm{Fe}$ as $\mathrm{FeO}$ 
Table 8. Samples used for high-temperature experiments as starting materials.

\begin{tabular}{|c|c|c|c|}
\hline \multicolumn{2}{|c|}{ nature of sample } & prepartion & analysis \\
\hline \multicolumn{2}{|c|}{$\begin{array}{c}\text { whole rock } \\
\text { (phenocryst +groundmass) }\end{array}$} & $\begin{array}{l}\text { ejecta of October } \\
\text { I3, } 1970\end{array}$ & $\begin{array}{c}\text { Table } 1 \\
\text { No. } 2\end{array}$ \\
\hline \multirow[t]{2}{*}{$\begin{array}{l}\text { groundmass } \\
\left(\begin{array}{l}\text { microlites } \\
\text { tglass }\end{array}\right)\end{array}$} & $\begin{array}{l}\text { GRM-3 } \\
\text { GRM-4 } \\
\text { GRM-5 }\end{array}$ & $\begin{array}{l}\text { mechanical separation } \\
\text { from rock powder (150 } \\
250 \text { mesh) by Clerici's } \\
\text { solution and isodynamic } \\
\text { separator }\end{array}$ & $\begin{array}{l}\text { Table } 1 \\
\text { No. } 8 \\
\text { No. } 9 \\
\text { No.10 }\end{array}$ \\
\hline & MIX -1 & \multirow{2}{*}{$\begin{array}{l}\text { artificial mixture from } \\
\text { reagents }\end{array}$} & $\begin{array}{c}\text { Table } 9 \\
\text { No. } 1\end{array}$ \\
\hline $\begin{array}{l}\text { glass in } \\
\text { groundmass }\end{array}$ & $\mathrm{MIX}-2$ & & $\begin{array}{c}\text { Table } 9 \\
\text { No. } 2\end{array}$ \\
\hline
\end{tabular}

Table 9. Chemical composition of synthetic mixtures. Prepared and analyzed by $H$. Haramura.

\begin{tabular}{l|r|r}
\hline & $\mathrm{MIX}-1$ & $\mathrm{MIX}-2$ \\
\hline $\mathrm{SiO}_{2}$ & 62.15 & 66.23 \\
$\mathrm{TiO}_{2}$ & 0.99 & 1.29 \\
$\mathrm{Al}_{2} \mathrm{O}_{3}$ & 14.45 & 11.26 \\
$\mathrm{FetO}_{3}$ & 9.96 & 10.00 \\
$\mathrm{MgO}$ & 2.05 & 1.08 \\
$\mathrm{CaO}$ & 5.84 & 4.49 \\
$\mathrm{Na}_{2} \mathrm{O}$ & 3.89 & 4.53 \\
$\mathrm{~K}_{2} \mathrm{O}$ & 0.60 & 0.86 \\
\hline $\mathrm{Total}$ & 99.93 & 99.74 \\
\hline $\mathrm{Q}$ & 21.42 & 26.56 \\
or & 3.54 & 5.08 \\
ab & 32.90 & 38.31 \\
an & 20.20 & 7.86 \\
wo & 3.66 & 6.02 \\
en & 5.10 & 2.69 \\
fs & 4.73 & 4.25 \\
mt & 6.50 & 6.52 \\
il & 1.88 & 2.45 \\
\hline
\end{tabular}

CIPW norms are calculated with the assumption $\mathrm{FeO}: \mathrm{Fe}_{2} \mathrm{O}_{\mathrm{a}}=55: 45$.

in an agate mortar under acetone or alcohol for at least 30 minutes. The size of the fragments was generally less than $2-3 \mathrm{mi}$ - crons but containing sporadic larger fragments. The second was prepared by heating original samples at 1200 to $1300^{\circ} \mathrm{C}$ for 22 to 40 hours in a platinum crucible in order to obtain a homogeneous glass. The crucible was preliminarily saturated with iron at the same conditions in respect to temperature and oxygen fugacity by using the original sample. After quenching, the complete melting was ascertained under the microscope. As it is impossible to mechanically separate volcanic glass in the groundmass, the composition of the glass was systhesized from reagent-grade chemicals ${ }^{1)}$ according to the Na-adjusted analyses of the glass (Table 9, MIX-2). The mixture was chemically analyzed to confirm its stoichiometry (Table 9). A part of the artificial mixture was ground fine and the other part was heated to get homogeneous glass. In order to check the difference in behavior during the runs between the natural and synthetic starting materials, another glass corresponding to the average groundmass composition was made as a control (MIX-1 in Tables 8 and 9).

1) Chemicals used are extra-pure grade $\mathrm{SiO}_{2}$ (quartz), $\mathrm{Fe}_{2} \mathrm{O}_{3}$ (hematite), $\mathrm{MgO}, \mathrm{Al}_{2} \mathrm{O}_{8}, \mathrm{Na}_{8} \mathrm{CO}_{3}, \mathrm{CaCO}_{3}$, $\mathrm{K}_{2} \mathrm{CO}_{3}$, and $\mathrm{TiO}_{2}$. 


\section{Experimental}

All the high-temperature runs were made in the laboratory at the Department of Chemistry, Tokyo Institute of Technology. Starting materials were held at the predetermined temperature to $\pm 1^{\circ} \mathrm{C}$ in an open-end $\mathrm{Pt40 \%} \mathrm{Rh}$ envelope suspended in the vertical $\mathrm{Pt} 40 \% \mathrm{Rh}$ resistance furnace. Controlling thermocouple (Pt13\%Rh-Pt) was frequently calibrated against the melting point of gold and diopside. The atmosphere was controlled by passing gas through the inner mullite tubing of the furnace (Katsura and Kimura, 1965). When the mixture of $\mathrm{CO}_{2}$ and $\mathrm{H}_{2}$ was used, the fluctuation of the mixing ratio was $\pm 0.1 \%$. The gas was passed at a rate of about $1 \mathrm{~cm} /$ sec. After the run, the envelope containing about $0.1-0.2 \mathrm{~g}$ of specimen was dropped into the bottom, cold part of the furnace, by electrically cutting the suspending wire. The envelope is quenched below red-hot state within a second. A thin section is made from the quenched specimen and the mineral phases are identified under a petrographic microscope.

Fudali (1965) showed that $\mathrm{Fe}^{3+} / \mathrm{Fe}^{2+}$ equilibration between the samples and the controlling atmosphere is reached within 20 to 50 hours at $1200^{\circ} \mathrm{C}$ for basaltic composition. The duration varied with the change of $\mathrm{f}_{\mathrm{O}_{2}}$. Shibata (1967) found in similar runs, the $\mathrm{Fe}^{3+} / \mathrm{Fe}^{2+}$ equilibration was reached after about 3 hours at $1300^{\circ} \mathrm{C}$ and 40 hours at $1200^{\circ} \mathrm{C}$. At temperatures as low as $1100^{\circ}$ $\mathrm{C}$ the equilibration time for basalt may be fairly long. At $1100^{\circ} \mathrm{C}$ in air, Kennedy (1948) found that degree of oxidation of iron in a basalt was not constant even after 240 hours of heating. This may be partly due to very high $\mathrm{f}_{\mathrm{O}_{2}}$ of the run. Accordingly, our runs were made for the period of $20-40$ hours at about $1200^{\circ} \mathrm{C}$ and for $150-200$ hours at about $1100^{\circ} \mathrm{C}$. Possibility that the $\mathrm{Fe}^{3+-}$ $\mathrm{Fe}^{2+}$ equilibration is not reached in runs at about $1100^{\circ} \mathrm{C}$ can not be denied, but even so deviation from equilibrium may not be great.

Three kinds of gas mixtures were used: 1) pure $\left.\mathrm{CO}_{2}, 2\right)$ a mixture with ratio $\mathrm{CO}_{2} /$ $\mathrm{H}_{2}=100$, and 3) that $\mathrm{CO}_{2} / \mathrm{H}_{2}=50$. The $\mathrm{f}_{\mathrm{O}_{2}}$ at a given set of mixing ratio and temperature may be calculated if the equilibrium can be assumed. However, deviation from ideal equilibrium state in the gas phase is strongly influenced by temperature, the flow rate of gas, structure of (especially temperature gradient within) the electric furnace, purity of the gas used, etc. In order to check the deviation, the $\mathrm{f}_{\mathrm{O}_{2}}$ of the controlling atmosphere at the hot spot of the furnace actually used for the experiment was measured directly with the use of the solid electrolyte cell composed of $\left(\mathrm{ZrO}_{2}\right)_{0.85}$ $(\mathrm{CaO})_{0.15}$ described in a previous paper (Katsura and Hasegawa, 1967). It was apparent that either at temperatures lower than $1100^{\circ} \mathrm{C}$ or at flow rate considerably larger than $1 \mathrm{~cm} / \mathrm{sec}_{\text {, }}$ the calculated $\mathrm{f}_{\mathrm{O}_{2}}$ deviates from the actual $f_{\mathrm{O}_{2}}$. The values of $\mathrm{f}_{\mathrm{O}_{2}}$ given in this paper are those directly measured.

\section{Identification of phases.}

Following phases are encountered; glass, magnetite, hematite, clinopyroxene, orthopyroxene, and plagioclase. Glass is brown-colored, transparent and isotropic. It forms the bulk of the charge and exhibits meniscus upper surface which was in direct contact with the controlling atmosphere during the runs. Magnetite occurs as octahedrons and hernatite as hexagonal plates. Occurrence of hematite is limited only to a few cases (e.g. runs at $1160^{\circ} \mathrm{C}$ for MIX-1, $\mathrm{CO}_{2}$ atmosphere) and is clearly indicative of the failure of proper control of $f_{\mathrm{O}_{2}}$ below the 


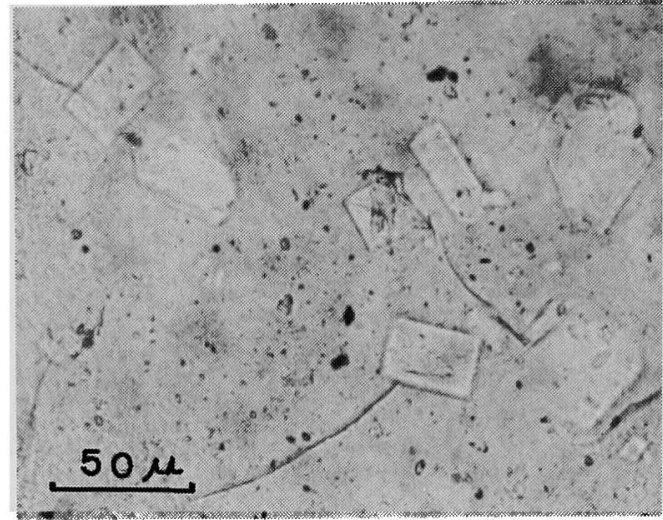

Fig. 12. Photomicrograph of plagioclase grown in finely ground natural samples (GRM-5).

stability field of hematite. Plagioclase invariably shows acicular or thin prismatic habit when it nucleated from the remelted glass while it shows stout prismatic habit when grown in finely ground natural samples (Fig. 12). In the latter case it probably grew over the tiny fragments of the natural plagioclase crystals. Clinopyroxene occurs also in acicular or thin prismatic forms in the remelted glass but shows a tendency to be more stout prismatic in finely ground natural materials. In some cases, very small amount of irregular small grains of clinopyroxene with a deep yellowish color are found lining the top surface of the charge, where fine magnetite crystals are markedly less abundant than in the inner main part of the charge. These yellow clinopyroxene crystals are regularly found at temperatures about $10-20^{\circ} \mathrm{C}$ higher than that where either clino- or orthopyroxene crystals first appear in the inner main part of the charge (see Figs. 13 and 14). Semiquantitative analysis by microprobe indicates that these crystals are extraordinarily rich in $\mathrm{Al}$ as compared with the normal clinopyroxenes. Occurrence of these yellow clinopyroxene is ignored in the following discussions on the basis that they are pro-

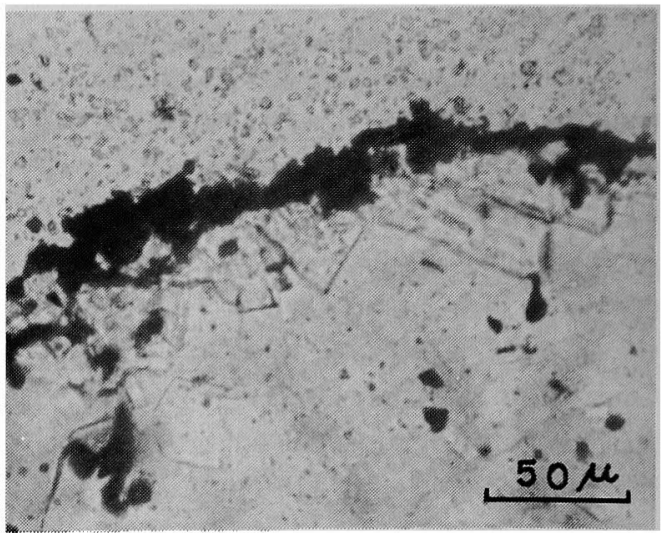

Fig. 13. Photomicrograph of the section cutting meniscus surface of a charge (BULK, run at about $1132^{\circ} \mathrm{C}, 86$ hours, in $\mathrm{CO}_{2}$ atmosphere). Magnetite grains (black) line the surface of the charge, and immediately below are prisms of yellowish clinopyroxene. Plagioclase is a!s p present.

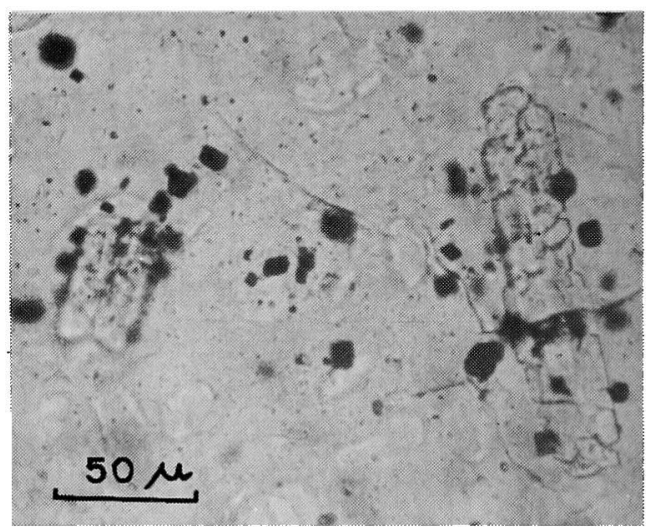

Fig. 14. Photomicrograph of orthopyroxene grown in finely ground natural samples (BULK, run at about $1114^{\circ} \mathrm{C}, 117$ hours, in $\mathrm{CO}_{2}$ atmosphere). Magnetite (black) and plagioclase (colorless, transparent) are also present.

bably the products of some local disequilibrium conditions whose mechanism is not yet well understood.

\section{Liquidus temperature at different oxygen fugacities.}

Results of the runs are summarized in Figs. 15 and 16 . Runs under different atmospheres (different sets of $f_{\mathrm{O}_{\mathbf{2}}}$ at varying 
temperature) were made on artificial mixtures (MIX-1 and MIX-2). The results of runs clearly indicate that the liquidus temperature of magnetite rapidly increases with increasing $\mathrm{f}_{\mathrm{O}_{2}}$ but that of plagioclase or clinopyroxene stays practically unchanged (within the resolution of the experiment) for the range of $\mathrm{f}_{\mathrm{O}_{2}}$ studied. In both cases of
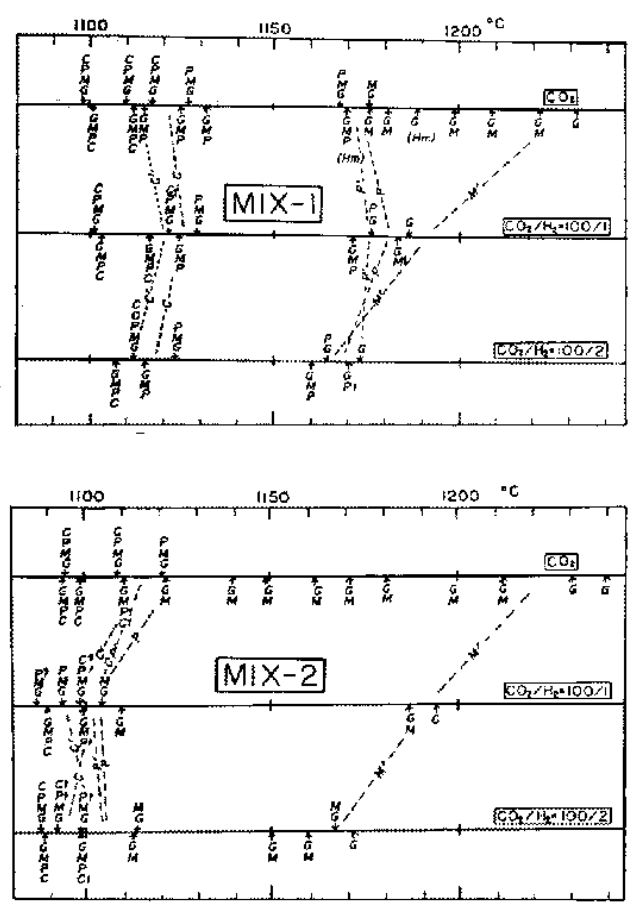

Fig. 15. Results of controlled-atmosphere, hightermperature experiments of artificial mixtures (MIX-1 and MIX-2). Symbols indicate kinds of mineral phases identified in the run product; G-glass, M-magnetite, Hm-hematite, P-plagioclase, C-clinopyroxene, $t$-trace in amount. Arrows indicate the temperature of the run. Run results above the horizontal line are for starting materials of finely ground powders and those below of remelted glass. Borken lines with letters $M, M^{\prime}$, etc. denote the liquidus temperature of magnetite, $\left(\mathrm{M}, \mathrm{M}^{\prime}\right)$, plagioclase $\left(\mathrm{P}, \mathrm{P}^{\prime}\right)$, and clinopyroxene $\left(C, C^{\prime}\right) . M, P$, and $C$ correspond to the liquidus temperatures with the starting materials of finely ground powders and $\mathrm{M}^{\prime}, \mathrm{P}^{\prime}$, and $\mathrm{C}^{\prime}$ to those of remelted glass. the two mixtures, the liquidus temperature is raised by more than $60^{\circ} \mathrm{C}$ for the corresponding difference in $\mathrm{f}_{\mathrm{O}_{\mathrm{g}}}$ of about $10^{-4}$ bars. This general relation has been already established by the studies made by Katsura (1969).

The $f_{\mathrm{O}_{2}}$ of the 1970 magma of Akitakomagatake may be estimated to be $10^{-9} \sim$ $10^{-10}$ bar at temperature of $1100^{\circ} \mathrm{C}$ from the crude extraporation of these results.

As varying $\mathrm{f}_{\mathrm{O}_{2}}$ does not practically change the liquidus temperature of plagioclase and pyroxene, most of the runs with natural samples were made in the controlling atmosphere of pure $\mathrm{CO}_{2}$, because runs with mixed gas atmosphere require much more attention than those with one kind of gas $\left(\mathrm{CO}_{2}\right.$ in this case), although the price had to be paid for certain degree of instability of $\mathrm{f}_{\mathrm{O}_{3}}$ due to impurities contained in commercial $\mathrm{CO}_{2}$, which sould have been avoided in runs with mixed gases because

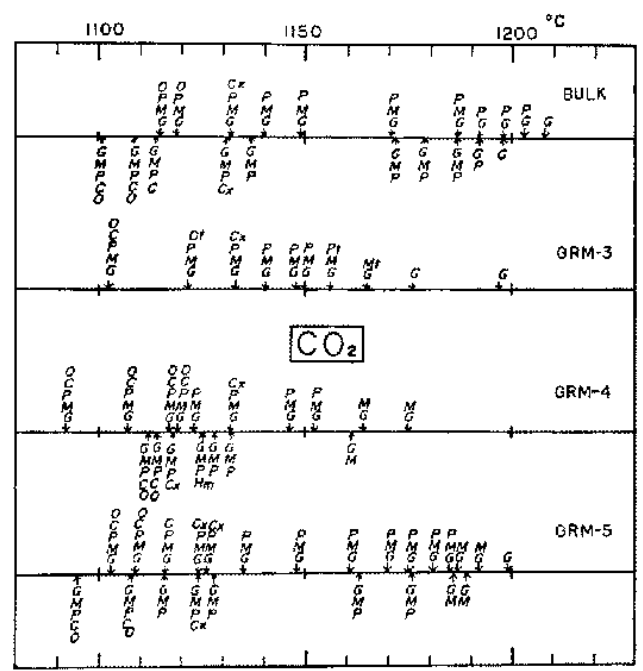

Fig. 16. Results of high-temperature experiments on natural samples of the 1970 ejecta of Akita-komagatake. All runs made in $\mathrm{CO}_{2}$ atmosphere. Symbols are the same as in Fig. 15 except $\mathrm{Cx}$ represents the yellowish clinopyroxene appearing only near the surface of the charge and $O$ orthopyrxene (see text). 
of the buffering effect of the mixed gases.

\section{Difference in liquidus temperature with presence or absence of crystal fragments as nucleii.}

In order to check the influence of structural prejudice of the starting materials, remelted glass and finely ground, but not remelted powders were used for the same composition (Figs. 15 and 16). It is apparent, in almost all cases, that the liquidus temperature (i.e. the highest temperature at which a certain mineral phase crystallizes out of the starting material) is lower in runs with remelted glass as starting materials than in those with finely ground powders. The discrepancy is usually $10 \sim 20^{\circ} \mathrm{C}$ for all the mineral phases. This is considered mainly due to difference in number of available nucleii in the starting materials, i.e. the remelted glass lost all the tiny fragments of crystals which otherwise would have played the role of effective nucleii. The

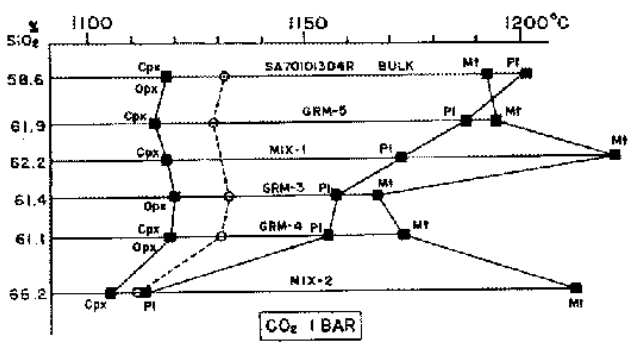

Fig. 17. Schematic diagram showing liquidus temperature relations of various starting materials from the ejecta of 1970 eruption of Akita-komagatake. Liquidus temperatures for $\mathrm{CO}_{2}$ atmosphere and finely ground powders as starting material. Open circles indicate temperature at which yellowish clinopyroxene appears near the surface of the charge. $\mathrm{SiO}_{2}$ weight percent is shown on extreme left. same tendency was found by Aramaki (1971) in hydrothermal conditions with rhyodacitic samples. Therefore, in the present study, the liquidus temperature is assigned using the results of runs with finely ground powders as starting materials. Fig. 17 shows simplified liquidus temperature relations for finely-ground starting materials of different composition in $\mathrm{CO}_{2}$ atmosphere.

\section{Liquidus Relations of the MAGMA}

\section{Correlation of liquidus temperature and composition}

As discussed in the foregoing, a marked difference in magnetite liquidus temperature encountered in the runs (Figs. 15 and 16) is greatly dependent on the redox state of iron. In more oxydizing conditions activity of $\mathrm{Fe}^{3+}$ is higher which is responsible for precipitation of magnetite at higher temperatures. ${ }^{1)}$

The liquidus temperature of pyroxenes and especially of plagioclase should not theoretically be affected greatly by the $\mathrm{Fe}^{3+}$ activity in the melt. On the other hand, the temperature of first appearance of plagioclase varies for more than $80^{\circ} \mathrm{C}$ as shown in Fig. 17, while the pyroxene liquidus stays roughly constant for the bulk and ground. mass compositions and only $10^{\circ} \mathrm{C}$ lower for the glass composition (MIX-2). This should be caused by difference in composition of the liquids other than the $\mathrm{Fe}^{3+} / \mathrm{Fe}^{2+}$ ratio. Among the oxide components, $\mathrm{CaO}$ and $\mathrm{Al}_{2} \mathrm{O}_{3}$ show the best correlation with the plagioclase liquidus temperature (see Fig. 18). This might indicate that the richer the plagioclase (An) "molecule" in the liquid

1) The anomalously high magnetite liquidus temperature of MIX-1 as compared with GRM-3, -4 , and -5 strongly suggests that the magnetite liquidus for MIX-2 is also excessively high. The reason is not yet fully known to us. 


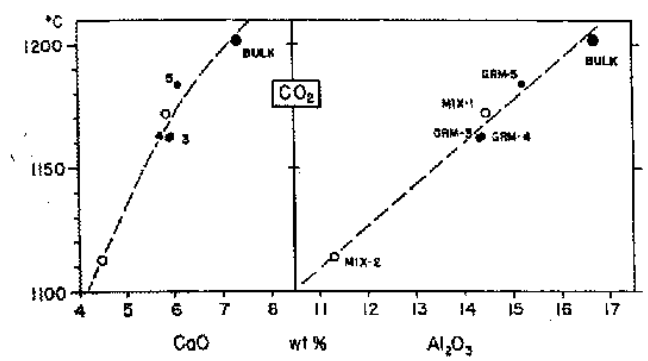

Fig. 18. Plots showing relations between plagioclase liquidus temperature and $\mathrm{CaO}$ and $\mathrm{Al}_{2} \mathrm{O}_{3}$ contents of the samples.

the higher the liquidus temperature.

In natural samples (BULK, GRM-3, -4 , and -5 ; Fig. 16), orthopyroxene and clinopyroxene appear at about the same temperature in each specimen, while in articial mixtures (MIX-1 and -2), only clinopyroxene is identified in the temperature range close to that of liquidus (with one exception, see Fig. 15). This may be explained by the difference in pyroxene "molecule" in the liquid. Fig. 19 shows that compositions of normative pyroxenes of the starting materials (same $\mathrm{Fe}^{\mathrm{a}+} / \mathrm{Fe}^{\mathrm{a}+}$ ratio as GRM-3 is assumed for MIX-1 and -2). It is apparent

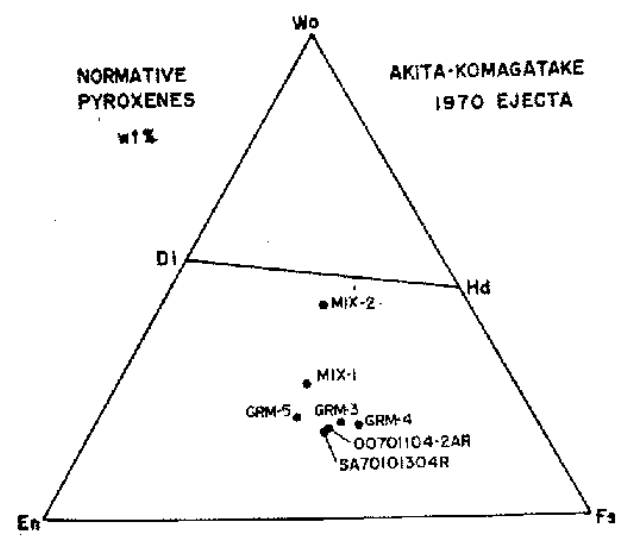

Fig. 19. Normative pyroxenes (in weight percent) of starting materials used in experiments. $00701104-2 \mathrm{R}$ is for the bulk composition of the ejecta of November 4,1970 (No. 3, Table 1). that MrX-1 and -2 are richer in wollastonite molecule and therefore may be in the primary field of clinopyroxene while the natural samples may lie close to the "two pyroxene boundary".

\section{A model for the 1970 magma of Akita- komagatake}

Suppose a body of liquid magma contained in the reservoir beneath a volcano. As cooling proceeds, crystals such as plagioclase and pyroxenes continue to precipitate from the magma. The liquidus temperature of a mineral phase is dependent on the composition of the liquid (magma), total pressure, partial pressures of $\mathrm{H}_{2} \mathrm{O}, \mathrm{O}_{2}$, etc. As the magma keeps cooling, or ascending from the depths to shallower conduit, the crystals keep precipitating with a decrease in volume of the liquid magma.

In case of the 1970-1971 eruption of Akita-komagatake, the essential material ejected out of the vent consisted of a liquid (magma) and grains of crystals. Of these crystal grains, larger ones (phneocrysts) are supposed to have crystallized while the magma was cooling slowly in the depths. The composition of the liquid at that time is represented by that of the "groundmass" of the ejecta. On the other hand, the volcanic glass in the groundmass must have been a molten liquid at the moment of ejection out of the vent. At what stage, then the small crystal grains (microlites) in the groundmass had crystallized out of the liquid.

As shown in Fig. 17, the liquidus temperatures of plagioclase and pyroxenes are markedly different for the compositions of the whole rock (BULK) and "groundmass" (GRM-3, -4 , and -5 ) but the same for that of groundmass glass $\left(1100^{\circ} \mathrm{C}\right)$. If the $f_{o_{a}}$ is lowered below that of the actually made runs, 
the liquidus temperature of magnetite should be lowered and finally match that of plagioclase and pyroxenes. In other words, a liquid with the composition of MIX-2 coexxists in equilibrium with plagioclase, pyroxene and magnetite at about $1100^{\circ} \mathrm{C}$ under the total pressure of 1 bar and $f_{\mathrm{O}_{2}}$ of $10^{-9} \sim$ $10^{-10}$ bar. These conditions correspond with those actually observed at the vent of Akita-komagatake (note that the observed temperature of the vent was $1090^{\circ} \mathrm{C}$, (Aramaki, 1972).

In order to make the liquids of the composition "whole rock" and "groundmass" to coexist in equilibrium with plagioclase, pyroxene(s), and magnetite, it is necessary to change significantly the physical conditions of the experiments described above. Lowering of $f_{\mathrm{O}_{2}}$ should effectively lower the magnetite liquidus temperature but the difference between liquidus temperature of plagioclase. and pyroxenes should remain.

Results of hydrothermal experiments made by Yoder (1965, etc.) on the system diopside-anorthite would be of interest in this concern. With increasing water pressure (=total pressure), the "eutectic" point between diopside and anorthite is lowered in temperature and shifted toward anorthiterich composition. At 1 bar dry, it is $1274^{\circ} \mathrm{C}$ and $\mathrm{Di}_{57} \mathrm{An}_{48}$ (wt \%) but at $\mathrm{P}_{\mathrm{H}_{2} \mathrm{O}}=5 \mathrm{kbar}$ it is about $180^{\circ} \mathrm{C}$ lower $\left(1095^{\circ} \mathrm{C}\right)$ and $\mathrm{Di}_{27} \mathrm{An}_{73}$.

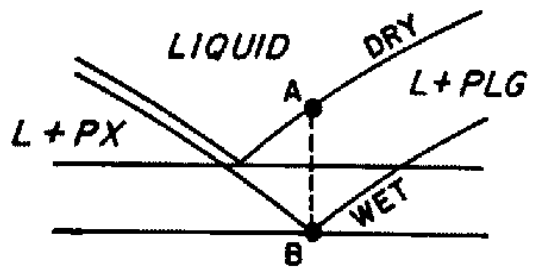

Fig. 20. Schematic diagram showing the liquidussolidus relations between plagioclase, pyroxene, and liquid magma. Vertical axis is temperature and horizontal composition. For explanation see text.
It may be not unreasonable to assume that essentially the same relation holds between natural liquid (magma) and plagioclase and pyroxene solid solutions (Yoder, 1969, etc.), which is schematically shown in Fig. 20. The horizontal axis indicates composition and the vertical axis temperature. Plagioclase component is on the far right end and pyroxene component far left. The upper horizontal line represents the temperature at which plagioclase and pyroxene coexist with a liquid in dry condition at 1 bar pressure, i.e., in the state of eruption at the earth's surface. The lower line represents the temperature at which liquid (magma) coexists with pyroxene and plagioclase under certain water pressure in the magma chamber or in the conduit. Point B indicates the composition of the liquid. If this liquid (magma) ascends in the conduit or is erupted to the surface, some crystals of plagioclase and pyroxene will precipitate but the rest will finally solidfy as glass. Thus the composition " $\mathrm{B}$ " corresponds to that of the "groundmass" which should show a plagioclase liquidus temperature appreciably higher than the "eutectic" temperature (-pyroxene liquidus).

Using this relationship, a model for the liquidus relations of the 1970-1971 magma of Akita-komagatake may be forwarded. Before the eruption, a liquid magma with a composition of the "groundmass" was precipitating plagioclase, hypersthene, augite, and magnetite in a deep reservoir under unknown but appreciable water pressure. The magma then rose through the conduit and finally erupted to the surface. During the ascent, as the confining pressure and probably water pressure also decreased, plagioclase, magnetite and mainly Ca-poor pyroxene kept crystallizing. The composition of the liquid followed the cotectic line be- 
tween the fields of these mineral phases and at the time of ejection out of the vent, it was close in equilibrium with precipitating minerals at 1 bar, dry condition.

If this model, although very crude, can approximate the magmatic condition, it may be possible to directly estimate the water and oxygen pressures and temperatures of the exupting magma by laboratory experiments using natural rock samples or simulated artificial mixtures. Hydrothermal experiments on natural andesites have been made by several workers (Hamilton et al., 1964; Fudali, 1965; Green and Ringwood, 1966, 1967, 1968; Eggler, 1972; etc.). These results indicate that as $\mathrm{P}_{\mathrm{H}_{2}} \mathrm{O}$ is raised, plagioclase liquidus rapidly drops while pyroxene liquidus does less rapidly, thus crossing occurs at certain, rather low water pressure. Judging from the difference of liquidus temperatures of plagioclase and pyroxenes of the "groundmass" of Akita-komagatake ejectas $\left(40 \sim 70^{\circ} \mathrm{C}\right.$ for GRM-3, $\left.-4,-5\right)$, the corresponding water pressure would be in the order of 200 to 500 bars. This appears to be in harmony with the physical factors observed during the eruption.

\section{REFERENCES}

Aramaki, S. (1971), Hydrothermal determination of temperature and water pressure of the magma of Aira caldera, Japan. Amer. Mineval., 56, 1760-1768.

(1972), Chemical composition of the rocks and rock-forming minerals, in Special issue on the 1970-1971 eruption of Akita-Komagatake. Bull. Volc. Soc. Japan, ser. 2, 16, 184-201 (in Japanese).

Aramaki, S., and Haramura, H. (1971), Petrological study of the new lava of Medake, Akita-komagatake. Volcanological Res. Eruption Akitakomagatake volcano, edit. J. Suzuki. Tohoku Univ., 99-108 (in Japanese).

Aramaki, S., Hirayama, K., and Nozawa, T. (1970), Chemical composition of Japanese granites. Part 1. Variation trends of 400 analyses. Bull. Earthq. Res. Inst., 48, 491-505.
(1972), Chemical composition of Japanese granites. Part 2, Variation trends and average composition of 1200 analyses. Jour. Geol. Soc. Japan, 78, 39-49.

Carmichael, I.S.E. (1967), The iron-titanium oxides of salic volcanic rocks and their associated ferromagnesian silicates. Contr. Mineral. Petrol., 14, 36-64.

Deer, W.A., Howie, R.A., and Zussman, J. (1963), Rock forming minerals, 4, 435p. Longmans, london.

Eggler, D.H. (1972), Water-saturated and undersaturated melting relations in a Paricutin andesite and an estimate of water content in the natural magna. Contr. Mineral. Petrol., 34, 261-271.

Fudali, R.F. (1965), Oxygen fugacities of basaltic andesitic magmas. Geochim. Cosmochim. Acta, 29, 1063-1075.

Green, T.H., and Ringwood, A.E. (1966), Origin of the calcalkaline igneous rock suite. Earth Planet. Sci. Letters, 1, 307-316.

(1967), Crystalilization of basalt and andesite under high pressure hydrous conditions. Earth Planet. Sci. Letters, 3, 481-489. (1968), Genesis of the calcalkaline igneous rock suite. Contr. Mineral. Petrol., 18, 105-162.

Hamilton, D.L., Burnham, C.W., and Osborn, E. F. (1964), The solubility of water and effects of oxygen fugacity and water content on crystallization in mafic magmas. Jour. Petrot., 5, 21-39.

Kano, H. (197I), On the magma eruption of Akita Komagatake volcano in 1970. Jour. Geol. Soc. Japan, 77, 47-51 (in Japanese).

Katsura, T. (1967), Pele's hair as a liquid of Hawaiian tholeitic basalts. Geochem. Jour., 1, 157-168.

Katsura, T. and Hasegawa, M. (1967). Equilibria in the $\mathrm{V}_{2} \mathrm{O}_{3}-\mathrm{VO}_{2}$ system at $1600^{\circ} \mathrm{K}$. Bull. Chem. Soc. Japan, 40, 561-569 (in Japanese).

Katsura, T. and Kimura, S. (1965), Equilibria in the system $\mathrm{FeO}-\mathrm{Fe}_{2} \mathrm{O}_{3}-\mathrm{MgO}$ at $1160^{\circ} \mathrm{C}$. Bull. Chem. Soc. Japan, 38, 1664-1670 (in Japanese).

Kawano, Y. and Aoki, K. (1959), Petrology of Hachimantai and adjacent volcanoes. Bull. Volc. Soc. Japan, ser. 2, 4, 61-76 (in Japanese).

(1960), Petrology of Hachimantai and surromding volcanoes, north-eastern Japan. Sci. Rept. Tohoku Univ., ser. 3, 6, $409-429$.

Kennedy, G.C. (1948), Equilibrium between volatiles and iron oxides in igneous rocks. Amer. Jour. Sci., 246, 529-549.

Kuno, H. (1950), Petrology of Hakone volcano and the adjacent areas, Japan. Geal. Soc. Amer. 
Bull., 61, 957-1020.

(1954), Volcanoes and volcanic rocks. Iwanami Zensho, Iwanami, Tokyo.

Lindsley, D.H. and Smith, D. (1971), Petrography and mineral chemistry of a differentiated flow of Picture Gorge basalt near Spray, Oregon, Chemical variations in the feldspars. Carnegie Inst. Year Book, 69, 274-278.

Macdonald, G.A. (1953), Pahoehoe, aa, and block lava. Amer. Jour. Sci., 251, 169-191.

Nakamura, $Y$, and Kushiro, I. (1970a), Compositional relations of coexisting orthopyroxene, pigeonite, and augite in a tholeitic andesite from Hakone volcano. Contr. Mineral. Petrol., 26, $265-275$.

[.. - - - - $(1970 \mathrm{~b})$, Equilibriım relations of hypersthene, pigeonite and augite in crystallizing magmas: microprobe study of a pigeonite andesite from Weiselberg, Germany. Amer. Mineral, 55, 1999-2015.

Ooshima, O. (1970), Compositional variation of magnetite during the eruption and its bearing on the stage of crystallization of magma of Futatsu-dake, Haruna volcano. Minral. Jour., 6, 249-263.

Ossaka, J. and Hirabayashi, J. (1972), Out-flow of lava and explosion of cinder on the eruption of Akita-komagatake. Bull. Volc. Soc. Japan, ser. 2, 16, 122-134 (in Japanese).

Shibata, K. (1967), The oxygen partial pressure of the magma from Mihara volcano, O-shima. Japan, Bull. Chem, Soc. Japan, 40, 830-834.

Suwa, A., Nagamune, T., and Watanabe, M. (1972), The outline of the 1970-71 eruption of Akita. komagatake. Bull. Volc. Soc, Japan, ser. 2,
16, 112-121 (in Japanese).

Tanaka, K. (1972a), The volcanic activity preceding the 1970 eruption, in special issue on the 1970-1971 eruption of Akita-komagatake. Bull. Volc. Soc. Japan, ser, 2, 16, 107-111 (in Japanese).

(1972b), Eruption earthquakes, in special issue on 1970-1971 eruption of Akita-komagatake. Bull. Volc. Soc. Japan, ser. 2, 16, 135142 (in Japanese).

Wentworth, C.K. and Macdonald, G.A. (1953), Structures and forms of basaltic rocks in Hawaii. U.S. Geol. Surv. Bull., 994, 98p.

Yagi, K. (1971), Geology of Akita-komagatake volcano, In special issue on 1970-1971 exuption of Akita-komagatake. Bull. Volc. Soc. Japan, ser. 2, 16, 80-89 (in Japanese).

Yagi, K., Takeshita, H., and Oba, Y. (1972), Petrological study on the 1970 eruption of Akitakomagatake volcano, Japan. Jour. Fac. Sci. Hokkaido Uniu., ser. 4, 15, 109-138.

Yagi, K., Oba, X., and Takeshita, H. (1971), Petrography and petrogenesis of the new lava of Akita-komagatake. Bull. Volc. Soc. Japan, ser. 2, 16, 174-183 (in Japanese).

Yoder, H.S.Jr. (1965), Diopside-anorthite-water at five and ten kilobars and its bearing on explosive volcanism. Carnegie Inst. Wash., Year Book., 64, 82-89.

(1969), Calcalkalic andesites: experimental data bearing on the origin of their assumed characteristics. Oregon Dept. Geol. Mineral. Ind. Bull., 65, 'Proceedings of andesite confeyence', 77-89.

\title{
秋田駒ケ岳 1970 年の噴火のマグマの岩石等と液相温度
}

\author{
荒牧 重 雄·桂
}

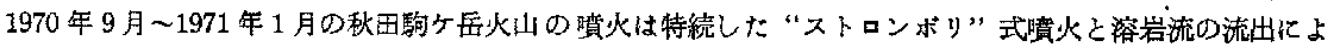

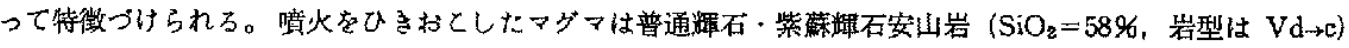

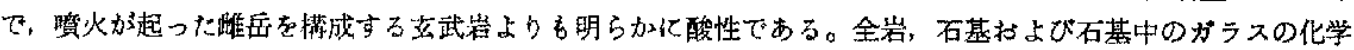

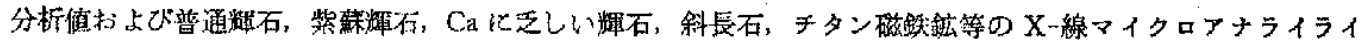

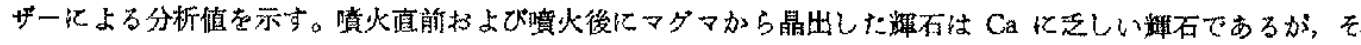
の組成はばらつるが大きく，隻安定な條件下で晶出したものと思われる。

新火山岩塊ねよびガラスの組成をるつ合成試料について酸素分圧を制御した高温実駼を行なったがその結 果暗出時のマグマの液相温度は約 $1100^{\circ} \mathrm{C}$ であり，噴火の際野外で実測された最高温度 $\left(1090^{\circ} \mathrm{C}\right)$ 飞近いとと

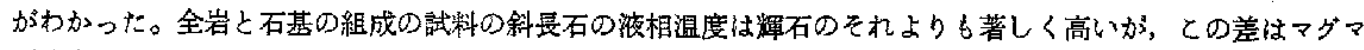
が噴出前地下深所方っった㫢の水蒸気压と噴火当時のそれとの差異に㴆せられる。 